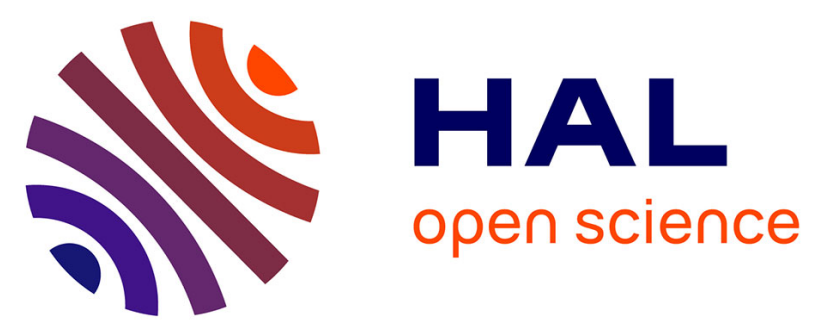

\title{
Cell-Associated HIV Cross-Presentation by Plasmacytoid Dendritic Cells Is Potentiated by Noncognate CD8 + T Cell Preactivation
}

Stéphane Isnard, Etienne Hatton, Marco Iannetta, Jean-Baptiste Guillerme, Anne Hosmalin

\section{To cite this version:}

Stéphane Isnard, Etienne Hatton, Marco Iannetta, Jean-Baptiste Guillerme, Anne Hosmalin. CellAssociated HIV Cross-Presentation by Plasmacytoid Dendritic Cells Is Potentiated by Noncognate CD8 + T Cell Preactivation. Journal of Immunology, 2021, 207 (1), pp.15-22. 10.4049/jimmunol.2000392 . hal-03453498

\section{HAL Id: hal-03453498 \\ https://cnrs.hal.science/hal-03453498}

Submitted on 29 Nov 2021

HAL is a multi-disciplinary open access archive for the deposit and dissemination of scientific research documents, whether they are published or not. The documents may come from teaching and research institutions in France or abroad, or from public or private research centers.
L'archive ouverte pluridisciplinaire HAL, est destinée au dépôt et à la diffusion de documents scientifiques de niveau recherche, publiés ou non, émanant des établissements d'enseignement et de recherche français ou étrangers, des laboratoires publics ou privés. 


\section{Cell associated HIV cross-presentation by PDC is potentiated by non-cognate CD8 T cell preactivation}

Stéphane Isnard*2, 3 , Etienne X. Hatton ${ }^{*}{ }^{3}$, Marco lannetta* 4, Jean-Baptiste Guillerme* and Anne Hosmalin*

*Université de Paris, Institut Cochin, CNRS, INSERM, F-75014 Paris, France

${ }^{2}$ Current address : Research Institute of the McGill University Health Centre, Montreal, Qc, Canada

${ }^{3}$ Contributed equally to this work.

${ }^{4}$ Current address : Tor Vergata University of Rome, Department of System Medicine, Rome, Italy

Corresponding author: Anne Hosmalin, anne.hosmalin@inserm.fr

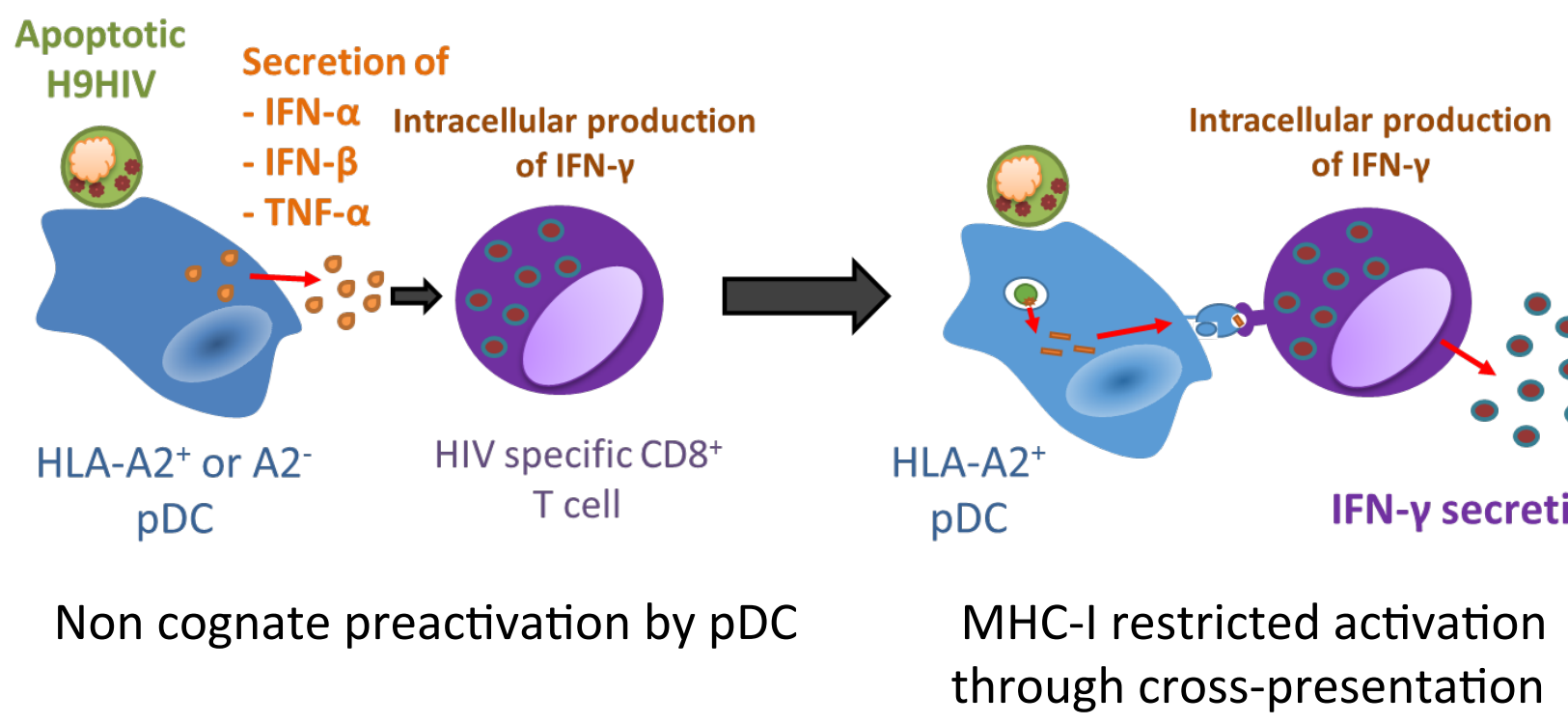

- HIV-infected H9 cells induce type I IFN production by pDC

- Type I IFN induces IFN- $p$ intracellular production in CD8 T cells

- pDC cross-present MHC-I-restricted HIV-Gag antigen to specific CD8 ${ }^{+} \mathrm{T}$ cells

- IFN- $\gamma$ secretion by CD8 ${ }^{+}$T cells is potentiated by former type I IFN stimulation, but occurs only in the case of cognate interaction with pDC 
4 Running title: HIV sensing by pDCs potentiates their crosspresentation

5 Stéphane Isnard ${ }^{*}{ }^{3}$, Etienne X. Hatton* ${ }^{3}$, Marco Iannetta ${ }^{4}$, Jean-Baptiste Guillerme* and Anne Hosmalin*

7 "Université de Paris, Institut Cochin, CNRS, INSERM, F-75014 Paris, France

8 Corresponding author: Anne Hosmalin, Tel +33 6306681 92, FAX +331405165 35,

9 anne.hosmalin@inserm.fr

10 Keywords : Antigen presentation (crosspresentation), Viral infection (HIV), Dendritic cells

11 (plasmacytoid DC, conventional DC), Cytotoxic cells (CD8 ${ }^{+} \mathrm{T}$ cells), Cytokines (IFN- $\gamma$, IFN-

$12 \alpha$, IFN- $\beta$ )

${ }^{1}$ This study was funded by the Association pour la Recherche sur le Cancer (ARC), the Ligue de recherche contre le Cancer-Ile-de-France, the French Government's Investissement d'Avenir program, Laboratoires d'Excellence "Integrative Biology of Emerging Infectious Diseases" (ANR-10-LABX-62-IBEID), the Agence Nationale de Recherche contre le Sida et les Hépatites Virales (ANRS), the Institut National de la Santé et de la Recherche Médicale (INSERM), the National Center for Scientific Research (CNRS) and Université Paris Descartes Sorbonne Paris Cité. SI and EXH received PhD studentships from Université Paris Descartes Sorbonne Paris Cité, MI from the Società Italiana di Malattie Infettive e Tropicali (SIMIT), ANRS and the ANR, and JBG a fellowship from the ANRS.

${ }^{2}$ Current address : Research Institute of the McGill University Health Centre, Montreal, Qc, Canada

${ }^{3}$ Contributed equally to this work.

${ }^{4}$ Tor Vergata University of Rome, Department of System Medicine, Rome, Ital 


\section{Abstract}

14 Human plasmacytoid dendritic cells (pDC) can cross-present antigens from apoptotic HIV-

15 infected cells or tumor cells to $\mathrm{CD}^{+} \mathrm{T}$ cells. As $\mathrm{pDC}$ respond to HIV virions by maturing and 16 secreting cytokines, we wondered whether these innate properties would affect cross-

17 presentation from HIV-infected cells. We incubated purified blood DC with apoptotic HIV-

18 infected $\mathrm{H} 9$ cells and then explored the activation process of $\mathrm{HIV}$-specific cloned $\mathrm{CD} 8^{+} \mathrm{T}$ cells,

19 in the presence of saquinavir We studied IFN- $\gamma$ secretion by HIV-specific T cells, which is

20 known to be tightly regulated by engagement of the T cell receptor. We found that HIV-specific

21 secretion by cloned HIV-specific $\mathrm{CD} 8^{+} \mathrm{T}$ cells was stimulated by $\mathrm{pDC}$ and $\mathrm{cDC} 1$ more than

22 by $\mathrm{cDC} 2$, and was strictly MHC-Class I (MHC-I)-restricted. Surprisingly, intracellular

23 production of IFN- $\gamma$ was only partly MHC-I restricted for $\mathrm{pDC}$, indicating a non-cognate $\mathrm{CD} 8^{+}$

24 T cell activation. Plasmacytoid DC, but not cDC, matured and secreted IFN- $\alpha$ in the presence

25 of apoptotic H9HIV cells. A cocktail of IFN- $\alpha$, IFN- $\beta$ and TNF- $\alpha$ induced intracellular

26 production of IFN- $\gamma$ but not Granzyme-B, mimicked the non-cognate mechanism, and neutralization of type I IFN signaling blocked non-cognate intracellular production of IFN- $\gamma$ in the co-culture model. Moreover, cognate stimulation was required to induce IFN- $\gamma$ secretion in addition to the cytokine cocktail. Thus, IFN- $\gamma$ secretion is tightly regulated by engagement of

30 the TCR as expected, but in the context of virus-infected cells, pDC can trigger intracellular

31 IFN- $\gamma$ accumulation in $\mathrm{CD}^{+} \mathrm{T}$ cells, potentializing IFN- $\gamma$ secretion once $\mathrm{CD}^{+} \mathrm{T}$ cells make cognate interactions. These findings may help manipulate type I IFN signaling to enhance specifically antigen-specific $\mathrm{CD} 8^{+} \mathrm{T}$ cell activation against chronic infections or tumors.

- HIV-infected H9 cells induce type I IFN production by pDC

- Type I IFN induces IFN- $\gamma$ but not Granzyme intracellular production in CD8 ${ }^{+} \mathrm{T}$ cells

- $\quad$ pDC cross-present MHC-I-restricted HIV-Gag antigen to specific CD8 ${ }^{+} \mathrm{T}$ cells

- IFN- $\gamma$ secretion is potentiated by type I IFN, but only upon cognate interaction 
39 HIV-specific $\mathrm{CD}^{+} \mathrm{T}$ cells activity is essential to achieve HIV control during acute and chronic

40 infection (1-8). To activate $\mathrm{CD}^{+} \mathrm{T}$ cell receptors (TCR) and induce antiviral and cytotoxic

41 responses, antigens must be presented as epitopes bound to class I major histocompatibility complex (MHC-I). In general, antigens that are synthesized in the cytosol of virus-infected

43 cells are digested by the proteasome, transported into the endoplasmic reticulum, where they

44 associate with nascent MHC-I molecules. MHC-I-peptide complexes are then exported to the

45 cell surface: this is the direct antigen presentation pathway, available in all cell types (9). The

46 direct antigen presentation pathway allows the detection and elimination of infected cells by

47 antigen-specific $\mathrm{CD} 8^{+} \mathrm{T}$-cells.

48 Dendritic cells (DC) are specialized in antigen presentation and activation of antigen-specific

49 T cells. They have specific antigen cross-presentation functions, allowing them to present

50 antigens which are not produced in their cytosol, but captured from other tissues, tumor cells

51 or infected cells $(10,11)$. They are poorly infected by HIV compared to $\mathrm{CD}^{+} \mathrm{T}$ cells,

52 especially because of their high expression of restriction factors (12). Hence, they probably

53 stimulate $\mathrm{HIV}$-specific $\mathrm{CD}^{+}$T-cells mainly by cross-presentation of exogenous antigens

54 produced in infected $\mathrm{CD}^{+} \mathrm{T}$ cells. During cross-presentation, antigens are engulfed into

55 endosomal/phagosomal compartments, and reach MHC-I molecules by either of two pathways:

56 endosome-to-cytosol translocation, then proteasomal digestion and transport into the ER or

57 phagosome; or endosomal pathway, where MHC-I molecules are fed by fusion with the

58 endoplasmic reticulum, and digestion is performed by local enzymes (13-15).

59 Among DC, CD8 $\alpha^{+} \mathrm{cDC} 1$ appeared to be specialized in cross-presentation in mice (16). Their

60 human homologs, $\mathrm{XCR} 1^{+} \mathrm{CD} 141^{+} \mathrm{cDC} 1$, express a collection of receptors for dead or dying

61 cells, chemokine receptors and adhesion molecules to interact with $\mathrm{CD} 8^{+} \mathrm{T}$ cells, and TLR for

62 microbial recognition, all converging toward a specialization for cross-presentation (17-20). 
63 However, the two other populations of human $\mathrm{DC}, \mathrm{CD} 1 \mathrm{c}^{+} \mathrm{cDC} 2$, and plasmacytoid DC (pDC),

64 have also been shown to be able to cross-present antigens $(18,21-23)$. Human immature pDC

65 have lower endocytic capacities than $\mathrm{cDC}$, and pDC were believed to be poor cross-presenting

66 cells. However, we have shown that pDC can cross-present HIV antigens $(18,21)$. Other

67 laboratories have also shown that pDC cross-presented antigens from Influenza A Virus (24-

68 27), tumors $(22,23,28,29)$ or Cytomegalovirus (28) either as cell-associated antigens, long

69 peptides, lipopeptides or particulate antigens. Similarly, murine pDC were also shown to be

70 able to perform cross-presentation $(30,31)$. In addition, pDC have exacerbated sensing

71 properties and strong inflammatory responses, particularly the production of interferon (IFN)-

$72 \alpha$, which has been shown to activate and increase $\mathrm{CD}^{+} \mathrm{T}$ cell function (32-34). Thus, some

73 laboratories have set up clinical protocols to induce antitumor responses using pDC lines or

$74 \mathrm{pDC}$ isolated from patient's blood, or combinations of $\mathrm{pDC}$ and $\mathrm{cDC}$, loaded with tumor

75 antigens $(28,35)$.

76 Our laboratory has shown that pDC cross-present HIV antigens to $\mathrm{CD}^{+} \mathrm{T}$ cell lines $(18,21)$.

77 As pDC can respond to HIV by maturation and secretion of different cytokines $(32,33)$, we

78 wondered how these innate responses to HIV-infected cells would affect cross-presentation.

79 To explore the activation process of $\mathrm{CD} 8^{+} \mathrm{T}$ cells by $\mathrm{pDC}$ compared to other $\mathrm{DC}$, we isolated

80 and expanded $\mathrm{CD}^{+} \mathrm{T}$ cell clones specific for an HIV-1 ${ }_{1 \mathrm{ai}}-\mathrm{Gag}$, HLA-A2-restricted epitope. We

81 tested the capacity of pDC to cross-present HIV-infected cell antigens to these CD8 ${ }^{+} \mathrm{T}$ cell

82 clones, which secreted IFN- $\gamma$ in response to cognate recognition. IFN- $\gamma$ secretion by specific T

83 cells is known to be tightly regulated, being triggered as very short ON/OFF cycles by

84 engagement of the TCR $(36,37)$. By comparing CD8 T cell clone activation by HLA-A2 ${ }^{+}$or

85 HLA-A2- DC, we uncovered a non-cognate intracellular pre-activation of these $\mathrm{CD}^{+} \mathrm{T}$ cells

86 by type I IFN produced by pDC upon stimulation by HIV-infected antigen-donor cells. 


\section{Materials and Methods}

88

89 Cytapheresis residues were obtained from healthy blood donors from the Etablissement

90 Français du sang (EFS) Crozatier-Saint-Antoine within a convention (C CPSL UST

91 18/EFS/030) between INSERM and EFS. Peripheral blood mononuclear cells (PBMC) were

92 isolated by Ficoll (Human pancoll, Dutscher, Issy les Moulineaux, France). DC were isolated 93 as previously described (38). Briefly, enriched DC were obtained by depleting CD19+ ${ }^{+}$or $\mathrm{CD}^{+}$ $\mathrm{B}$ cells, $\mathrm{CD}^{+}{ }^{\mathrm{T}}$ cells, $\mathrm{CD} 14^{+}$and or $\mathrm{CD} 6^{+}$monocytes, $\mathrm{CD} 56^{+} \mathrm{NK}$ cells, $\mathrm{CD} 9^{+}$platelets, $\mathrm{CD} 6 \mathrm{~b}^{+}$granulocytes and Glycophorin- $\mathrm{A}^{+}$erythrocytes from PBMC (Stemcell, Grenoble, France). Enriched DC were then sorted by FACS to isolate the different populations of blood DC according to the strategy depicted in the Supplemental Fig. 1A. All the cells were maintained in "complete medium" (RPMI 1640-glutamax containing $100 \mathrm{U} / \mathrm{mL}$ penicillin; 100 $\mathrm{mg} / \mathrm{mL}$ streptomycin, $1 \%$ nonessential amino acids, $1 \mathrm{mM}$ sodium pyruvate, $10 \mathrm{mM}$ HEPES buffer; Life Technologies, Saint-Aubin, France) supplemented with 2\% human albumin (Vialebex, LF Biomédicaments, Les Ulis, France). In all experiments but those of Sup Fig. 2B, to improve DC survival, we cultured pDC with $10 \mathrm{ng} / \mathrm{ml}$ IL-3 (Invivogen, Toulouse, France) and cDC with 1000 U/ml GM-CSF (Peprotech, Neuilly sur Seine, France). When indicated, we stimulated cDC1 with $30 \mu \mathrm{g} / \mathrm{ml}$ Poly I:C (Invivogen) and cDC2 with $100 \mathrm{ng} / \mathrm{ml} \mathrm{LPS}$ (Sigma). All cells were incubated in a humid incubator at $37^{\circ} \mathrm{C}, 5 \% \mathrm{CO}_{2}$. For each condition, DC were cultured at $10.10^{3}$ for ELISA or $25.10^{3}$ for flow cytometry in $200 \mu \mathrm{L}$, in 96 well plates, with "complete medium" and 2\% human albumin.

H9 and H9HIV-1 $1_{\text {IIIB }}$ cells were obtained from the NIH AIDS Reagent Program, Division of AIDS, NIAID from Dr. Robert Gallo $(39,40)$ and maintained in culture in "complete medium" $+10 \%$ Fetal Calf Serum (FCS, Life Technologies France). They were irradiated for 1 to 5 min 
111 by UV-C $(240 \mathrm{~mJ} / \mathrm{cm} 2)$ for apoptosis induction, and cultured overnight before culture with

112 DC. All experiments involving H9 and H9HIV cells were performed in the presence of

113 Saquinavir $(1 \mu \mathrm{M})$, a protease inhibitor used as an antiretroviral drug, to prevent direct

114 presentation of HIV, kindly provided by the NIH AIDS Reagent Program, division of AIDS,

115 NIAID, NIH.

116 T cell clones were obtained from PBMC of an HLA-A2 ${ }^{+}$HIV-infected donor (Prevac Cohort,

117 IRB 00003835, authorized by the CPP Ile de France IV, June 25, 2010). Briefly, PBMC were

118 pulsed with $\mathrm{HIV}-1-\mathrm{Gag}_{77-85}(41)$ short peptide for $1 \mathrm{~h}$ at $4{ }^{\circ} \mathrm{C}$, then incubated at $37^{\circ} \mathrm{C}, 5 \% \mathrm{CO}_{2}$

119 for $4 \mathrm{~h}$, and IFN- $\gamma$ producing cells were magnetically purified using the IFN- $\gamma$ secretion Assay

120 (Miltenyi, Paris, France). Cells were then cloned by limiting dilution on irradiated feeders

121 (PBMC and LAZ cells; kind gift from Dr. Fonteneau, Nantes, France) and amplified in

122 "complete medium", with 8\% AB-negative heat inactivated human serum, $150 \mathrm{U}$ IL-2/mL

123 (Chiron or Miltenyi) and PHA-L (Millipore, Molsheim, France) as in (42). After amplification,

124 cell specificity was confirmed by incubating $\mathrm{T}$ cell clones overnight with HIV-1 $1_{\text {lai }}-\mathrm{Gag}$ 77-85

125 peptide-pulsed HLA-A2 ${ }^{+}$B cell blasts (Supplemental Fig. 2A). Supernatants were collected

126 and IFN- $\gamma$ measured by ELISA (Mabtech, Courtaboeuf, France). Background IFN- $\gamma$ secretion

127 with a control Flu peptide (H1N1-A/PR8 58-66) was usually less than $1 \%$ of the signal obtained

128 with HIV-1-Gag $77-85$ peptide. Percentage of HIV-1-Gag specific cells was analyzed by flow

129 cytometry as described below. More than $95 \%$ of $\mathrm{CD}^{+} \mathrm{T}$ cell clones produced IFN- $\gamma$ in

130 response to their cognate antigen. For experiments involving $\mathrm{CD} 8^{+} \mathrm{T}$ cell clones only, $25.10^{3}$

131 cells were cultured in $200 \mu \mathrm{L}$ in "complete medium" with $8 \%$ AB-negative heat-inactivated

132 human serum.

133 Flow cytometry

134 For DC isolation from DC-enriched PBMC, as described in (38), Live/Dead Yellow

135 (Thermofisher) was used to exclude dead or dying cells. The following antibodies were diluted 
in labeling buffer (PBS, $2 \mathrm{mM}$ EDTA, 0.5\% BSA) and incubated with the cells for 20 min on

137 ice; anti human CD1c (BDCA-1) Pacific Blue (Biolegend, L161 clone, diluted at 1/400), 138 CD141 (BDCA-3) APC-Vio770 (Miltenyi, AD5-14H12 1/50), CD304 (BDCA-4) PE-Vio770 139 (Miltenyi, AD5-17F6 1/20) and CD3/14/16/19/20/56 (Lin1) FITC (BD, SK7, 3G8, SJ25C1, 140 L27, MphiP9, NCAM16.2 1/50), as in (38). Cells were then washed and purified by FACS

141 (FACS ARIA, Beckton Dickinson or ASTRIOS, Beckman Coulter) with $>95 \%$ purity 142 (Supplemental Fig. 1A). From 1 billion PBMC per donor, we usually sort 1 million and more 143 of pDC and cDC2, compared to 0.15 million cDC1 only (38). For DC maturation assays, anti144 human CD1c Pacific Blue (Biolegend, L161 1/400), CD141 PE (BD, 1A4), CD123 APC 145 (Miltenyi, AC145 1/50), CD3 APC-H7 (BD, SK7 1/50), CD83 PE-Cy5 (BD, HB15e 1/30) and CCR7 FITC (R\&D, FAB1971 1/30) were used.

147 For assessment of $\mathrm{CD}^{+} \mathrm{T}$-cell function (38), 2 PBS washes were performed before adding 148 Live/Dead Blue (Life Technologies), then Fc Block (5\% Human Serum (Dutscher) on ice. 149 Anti-human CD1c Pacific Blue (Biolegend, L161 1/400); CD141 PE-Cy7 (Miltenyi, AD5150 14H12 1/100); CD123 PE-Cy5 (Biolegend, 6H6 1/50); CD3 APC-H7 (BD, SK7 1/50); CD8 151 FITC (BD, SK1 1/50); and HLA-A2 PE (BD, BB7.2 1/50) diluted in labelling buffer were 152 incubated with the cells for $20 \mathrm{~min}$ on ice for surface staining. Cells were then washed twice 153 in labeling buffer, fixed for $15 \mathrm{~min}$ in PBS PFA 4\%, washed again and incubated with anti 154 IFN- $\gamma$ APC (Sony, B27 1/20) in PBS, 0.1\% BSA, 0.1\% saponin for $45 \mathrm{~min}$ on ice for 155 intracellular staining. Cells were washed twice in PBS containing BSA and saponin, and 156 resuspended in labeling buffer before acquisition on a LSR II flow cytometer (BD 157 Biosciences).

159 After incubation with cytokines for $4 \mathrm{~h}$ on poly-D-lysine (Millipore)-coated coverslips, cells 160 were washed once with PBS and fixed using 4\% PFA in PBS for 15 min at room temperature. 
161 Permeabilization and blocking were performed using PBS 0.1\% Saponine 0.1\% BSA 5\%

162 Human Serum for 30 min at room temperature. Labeling was performed using anti-CD3 rabbit 163 polyclonal antibodies (Dako, 1/100), anti-human Granzyme-FITC (Sony, GB11 1/20) and 164 anti-human IFN- $\gamma$-APC (Sony, B27 1/5) for $1 \mathrm{~h}$ at room temperature. After washing, Goat anti165 Rabbit $\operatorname{IgG}\left(\mathrm{H}^{+} \mathrm{L}\right)$ Alexa Fluor 546 (Invitrogen, 1/200) were added for $45 \mathrm{~min}$ at room 166 temperature. DAPI was used to stain the nucleus. Fluoromount-G (Invitrogen) was used to 167 mount the slides. Images were taken using a confocal microscope (Leica DMI6000, spinning 168 disk Yokogawa CSU-X1M1) and analyzed with ImageJ software.

\section{Antigen cross-presentation assay}

171 We improved the model established in the laboratory (21) by using $\mathrm{CD}^{+} \mathrm{T}$ cell clones (38).

172 We incubated UV-C irradiated HIV-1 infected H9 cells (which do not express HLA-A2) with blood DC isolated from HLA-A2 ${ }^{+}$or HLA-A2 ${ }^{-}$donors (5 H9 cells per DC), stimulated or not as indicated, in the presence of saquinavir. After overnight co-culture and washes, we added the HIV-1 Gag $77-85$ specific CD8 ${ }^{+} \mathrm{T}$ cell clone (1 T cell per DC) overnight in the presence of

176 survival factors (IL-3 for $\mathrm{pDC}$, GM-CSF for $\mathrm{cDC}$ ) and measured IFN- $\gamma$ in the supernatant by 177 ELISA (Mabtech, France). Alternatively, we added the specific $\mathrm{CD} 8^{+} \mathrm{T}$ cell clone only for $4 \mathrm{~h}$ 178 in the presence of Brefeldin A (BFA, Sigma, St Quentin Fallavier, France) and in the absence 179 of survival factors, and analyzed IFN- $\gamma$ intracellular production by flow cytometry. To assess 180 the role of type I IFN or TNF- $\alpha$, neutralizing antibodies specific for IFN- $\alpha$, IFNAR (PBL) or 181 TNF- $\alpha$ (Peprotech) were added at $10 \mu \mathrm{g} / \mathrm{ml}$ for $30 \mathrm{~min}$ before incubation with the CD8 ${ }^{+} \mathrm{T}$ cell 182 clone, and IFN- $\gamma$ intracellular production was analysed by flow cytometry. 
$18525.10^{3}$ Dendritic cells were separately incubated overnight in $200 \mu$ of complete medium + $1862 \%$ human albumin with either H9 or H9HIV cells at a 1 DC to 5 H9/H9HIV ratio in the

187 presence of saquinavir and IL-3 (pDC) or GM-CSF (cDC1 and cDC2). Cells were then labeled 188 and analyzed by flow cytometry. IFN- $\alpha$ was quantified in the supernatants by ELISA 189 (Mabtech).

190

\section{$\mathrm{CD8}^{+} \mathrm{T}$ cell clone stimulation by cytokines or anti-CD3/CD28 beads}

192 Recombinant PEGylated IFN- $\alpha$ (Roche), IFN- $\beta$ (Roche) or TNF- $\alpha$ (Peprotech) were added at 193200,100 and $50 \mathrm{ng} / \mathrm{ml}$ respectively, on $\mathrm{CD}^{+} \mathrm{T}$ cell clones for $4 \mathrm{~h}$ in the presence or absence 194 of BFA. To mimic cognate interaction with DC, 2 anti-CD3/CD28 beads (Life Technologies) 195 per $\mathrm{CD}^{+} \mathrm{T}$ cell were added for $4 \mathrm{~h}$ before supernatant collection. IFN- $\gamma$ was analysed by 196 intracellular labeling or by ELISA as above.

\section{Statistics}

199 Results are given as medians (95\% confidence intervals). All tests were realized with GraphPad

200 Prism v6.10 for Mac OS X. The Wilcoxon test was used to compare IFN productions in response to DC incubated with H9 vs H9HIV. Otherwise, Mann-Whitney tests were applied to compare two different groups, and Kruskal-Wallis test with Dunn's post-test corrections were applied to compare more than two groups. 
209 To understand how different types of human blood DC interact with apoptotic HIV-infected

210 antigen-donor cells and $\mathrm{CD}^{+} \mathrm{T}$ cells during cross-presentation, we set up a culture system as

211 previously published, in the presence of saquinavir to eliminate HIV replication and direct

212 presentation $(18,21,38)$. Dendritic cells were purified from buffy coats by immunomagnetic

213 sorting, then by flow cytometric cell sorting, yielding typically $150000 \mathrm{cDC} 1,1,3 \times 106 \mathrm{cDC} 2$

214 and 1,2 x 106 pDC. They were incubated overnight with apoptotic H9 or H9HIV cells in the

215 presence of survival factors (IL-3 for $\mathrm{pDC}$, or GM-CSF for $\mathrm{CDC}$ ). To make sure of the origin

216 of IFN- $\gamma$, we measured in parallel the secretion of IFN- $\gamma$ by the $\mathrm{CD}^{+} \mathrm{T}$ cell clone in the

217 supernatants (Fig. 1A), and the intracellular production of IFN- $\gamma$ (Fig. 1B). IFN- $\gamma$ secretion

218 was specific for HIV, as it was only detected with apoptotic H9HIV cells and not with apoptotic uninfected H9 cells (Fig. 1A; for pDC: median 104 (95\% confidence interval 57-256) vs 0 (0-

5) $\mathrm{pg} / \mathrm{ml}$, Wilcoxon $\mathrm{p}<0.0001$; for $\mathrm{cDC} 1$ : 66 (35-153) vs 11 (2-18) $\mathrm{pg} / \mathrm{ml}, \mathrm{p}=0.008$; for $\mathrm{cDC} 2$ : $30(17-57)$ vs $0(0-4) \mathrm{pg} / \mathrm{ml}, \mathrm{p}=0.0005)$. As expected, IFN- $\gamma$ secretion by the $\mathrm{CD} 8^{+} \mathrm{T}$ cell clone was MHC-I restricted, as it was detected only in the presence of HLA-A2 ${ }^{+}$, but not HLA-A2DC (Fig. 1A). Comparing HLA-A2-restricted cross-presentation by the different DC populations, no statistical difference was found between the levels of IFN- $\gamma$ secretion induced in the presence of $\mathrm{pDC}$ and $\mathrm{cDC} 1$, whereas the levels induced by $\mathrm{cDC} 2$ were lower (Mann Whitney $\mathrm{p}=0.0008$ for $\mathrm{pDC}$ vs $\mathrm{cDC} 2$ and $\mathrm{p}=0.04$ for $\mathrm{cDC} 1$ vs $\mathrm{cDC} 2)$. Conversely to $\mathrm{pDC}$, cDC1 and $\mathrm{cDC} 2$ required TLR activation (TLR3 for $\mathrm{cDC} 1$ and TLR4 for $\mathrm{cDC} 2$ ) to perform cross-presentation (Fig. 1 A). IFN- $\boldsymbol{\gamma}$ intracellular production was also specific for HIV, as it 
was only detected when DC were cultured with infected H9HIV cells, and not with uninfected H9 cells (Fig. 1B; for pDC: median $16.8 \%(11.3-20.8)$ vs $0.7 \%(0.5-1.6)$, Wilcoxon $p=0.0005$; for $\mathrm{cDC} 1: 13.5 \%(1.3-31.0)$ vs $2 \%(0.0-5.2), \mathrm{p}=0.03$; for $\mathrm{cDC} 2$ : 4 (1.6-5.2) vs $0.5 \%(0.3-1.4)$,

$232 \mathrm{p}=0.01)$. Again, $\mathrm{pDC}$ and $\mathrm{cDC} 1$ induced similar levels of intracellular IFN- $\gamma$ production by the $233 \mathrm{CD}^{+} \mathrm{T}$ cell clone, and higher levels than cDC2 (Mann-Whitney $\mathrm{p}<0.0001$ for $\mathrm{cDC} 2 \mathrm{vs} \mathrm{pDC}$ and $\mathrm{p}=0.01$ for $\mathrm{cDC} 2 \mathrm{vs} \mathrm{cDC} 1)$. Surprisingly, $\mathrm{CD} 8^{+} \mathrm{T}$ cell intracellular production of IFN- $\gamma$ was also stimulated in a non-cognate manner by HLA-A2- ${ }^{-}$DC incubated with H9HIV cells, and not with uninfected H9 cells $(8.9 \%(6.4-11.1)$, vs $0.3 \%(0.1-1)$ Wilcoxon $p=0.002)$, although weaklier than by HLA-A2 ${ }^{+} \mathrm{pDC}$ (Mann-Whitney $\mathrm{p}=0.01$ ). HLA-A2- $\mathrm{cDC} 1$ from one $/ 4$ donors induced $76 \mathrm{pg} / \mathrm{mL}$ IFN- $\gamma$ production, and from another $3.4 \%$ IFN- $\gamma$-positive $\mathrm{CD}^{+} \mathrm{T}$ cells upon stimulation with HIV-1 infected cells and poly(I:C), indicating an occasional, but not significant, potential of these cells for inducing non-cognate responses. HLA-A2 ${ }^{-}$cDC2 from the 14 donors did not induce any significant non-cognate response upon stimulation with H9HIV cells and LPS. IL-3 was added to improve pDC viability but otherwise had no effect on $\mathrm{CD}^{+} \mathrm{T}$ cell responses (Supplemental Fig. 2B). Therefore, HIV-specific secretion of IFN- $\gamma$ by the antigen-specific $\mathrm{CD}^{+} \mathrm{T}$ cells was stimulated by $\mathrm{pDC}$ and both cDC populations and was strictly MHC-I restricted. In contrast, HIV-specific intracellular production of IFN- $\gamma$ by $\mathrm{CD} 8^{+} \mathrm{T}$ cells was only partly MHC-I restricted for $\mathrm{pDC}$, indicating a non-cognate $\mathrm{CD} 8^{+} \mathrm{T}$ cell activation.

pDC, and not $\mathrm{cDC}$, matured and produced IFN- $\alpha$ in the presence of HIV-infected apoptotic cells

251 We investigated the mechanisms of the non-cognate $\mathrm{CD} 8^{+} \mathrm{T}$ cell activation found in culture 252 with pDC and H9HIV cells. HIV virions are known to induce maturation and IFN- $\alpha$ secretion 
by $\mathrm{pDC}$, but not $\mathrm{cDC}$, thus we tested these two parameters in the different populations of

254 purified DC cultured in the presence of apoptotic HIV-infected H9 cells (Fig. 2). Expression 255 of the chemokine receptor CCR7 and the costimulatory molecule CD83, which are known to 256 be induced on pDC by HIV-1 virions (43), were analyzed by flow cytometry (Fig. 2A). pDC 257 cultured with apoptotic H9HIV cells expressed CCR7 and CD83, but cDC did not. The three 258 populations of purified DC were however able to mature by upregulating CCR7 and CD83 expression, when mixed again and cultured all together and not separately with apoptotic H9HIV cells (Fig.2A), as in (43) with HIV virions. Apoptotic uninfected H9 cells did not induce significant changes in CCR7 or CD83 expression by DC. In the supernatants from purified DC populations, we detected high amounts of IFN- $\alpha$ when purified $\mathrm{pDC}$ were cultured with apoptotic H9HIV cells, but not H9 cells (median $21(3-86)$ vs $0.1(0.1-0.3) \mathrm{ng} / \mathrm{ml}$, Wilcoxon $\mathrm{p}=0.004$ ) (Fig. 2B). In contrast, no IFN- $\alpha$ secretion was detected in $\mathrm{cDC} 1$ or $\mathrm{cDC} 2$ co-culture. Thus, only purified $\mathrm{pDC}$, and not purified $\mathrm{cDC}$, matured and secreted IFN- $\alpha$ when cultured with HIV- infected H9 cells.

Type I IFN and TNF- $\alpha$ induced IFN- $\gamma$ intracellular production by $\mathrm{CD8}^{+} \mathbf{T}$ cells,

270 As IFN- $\alpha$, IFN- $\beta$ and TNF- $\alpha$ are produced by $\mathrm{pDC}$ and not by $\mathrm{cDC} 1$ or cDC2 in response to 271 HIV virions $(32,33)$, and as IFN- $\alpha$ was produced by pDC and not by cDC1 or cDC2 in response to H9HIV cells, we tested whether these cytokines would have a direct activity on $\mathrm{CD} 8^{+} \mathrm{T}$ cells and could explain the non-cognate $\mathrm{T}$ cell activation. We incubated cloned $\mathrm{CD} 8^{+} \mathrm{T}$ cells alone

274 for $4 \mathrm{~h}$ with recombinant cytokines, at concentrations similar to those secreted by pDC in the 275 presence of $\operatorname{HIV}(32,33)$ or H9HIV cells. By flow cytometry, $2.9 \%((1-6.2)$ to $3.9 \%(0.8-5.4)$ 
in combination (Fig 3A, median 2.9\%, 2.9\% and 3.9\% respectively; Dunn's post-test $\mathrm{p}=0.3$,

0.1 and 0.1 respectively), but not after incubation with TNF- $\alpha$ alone (median $0.1 \%$ ). However, a combination of IFN- $\alpha$, IFN- $\beta$ and TNF- $\alpha$ strongly stimulated IFN- $\gamma$ production by a median of $10 \%(5.7-13.0)$ of the $\mathrm{CD}^{+} \mathrm{T}$ cells compared to medium only $(0 \%(0.0-0.1)$, Fig. $3 \mathrm{~A}$, Dunn's post-test $\mathrm{p}=0.009)$. The percentage of $\mathrm{CD} 8^{+} \mathrm{T}$ cells expressing IFN- $\gamma$ was 2.6 times higher after addition of TNF- $\alpha$ than after IFN- $\alpha$ and IFN- $\beta$ alone, indicating a potential synergy, but the results were not statistically different (median $10 \%(5.7-13.0)$ vs $3.9 \%(0.4-7.9)$ of IFN$\gamma^{+} \mathrm{CD}^{+} \mathrm{T}$ cells, Wilcoxon $\left.\mathrm{p}=0.25\right)$. This stimulation by the three cytokines induced approximately the same percentage of IFN $-\gamma^{+} \mathrm{CD} 8^{+} \mathrm{T}$ cells as observed after stimulation with HLA-A2 ${ }^{-}$pDC incubated with apoptotic H9HIV cells (8.9\% (6.4-11.0) Fig. 1B). Indeed, intracellular IFN- $\gamma$ production by the $\mathrm{CD} 3^{+} \mathrm{CD} 8^{+} \mathrm{T}$ cell clone was detected using confocal microscopy after stimulation with IFN- $\alpha$, IFN- $\beta$ and TNF- $\alpha$ (28 IFN- $\gamma$ positive cells out of 60 cells) compared to medium alone (NS) (0 IFN- $\gamma$ positive cells out of 18 cells) (Fig. 3B). Interestingly, intracellular Granzyme B was expressed in different vesicles from IFN- $\gamma$ in $100 \%$ of the cells and did not depend on stimulation by the cytokine cocktail. By contrast to intracellular production, IFN- $\boldsymbol{\gamma}$ secretion was not induced by these three cytokines added in combination (Fig 3C). We have seen that IFN- $\gamma$ secretion by the $\mathrm{CD} 8^{+} \mathrm{T}$ cell clone required cognate interaction with HLA-A2 ${ }^{+}$DC. To mimic cognate stimulation by MHC-peptide complexes (signal 1) and co-stimulation (signal 2) (44), without adding HIV and its pathogenassociated molecular patterns (PAMPs), we used anti-CD3 and -CD28 antibody-coated beads, which induced a weak but consistent IFN- $\gamma$ secretion from the $\mathrm{CD}^{+} \mathrm{T}$ cells (median $93 \mathrm{pg} / \mathrm{mL}$, $\min 22, \max 286 \mathrm{pg} / \mathrm{mL}, \mathrm{n}=6$, Fig. $3 \mathrm{C}$ ). This secretion was normalized to 1 to compare the effect of the cytokines in multiple experiments. Adding beads to IFN- $\alpha$, IFN- $\beta$ or TNF- $\alpha-$ stimulated cells increased IFN- $\gamma$ secretion without reaching statistical significance (median 2, 
and IFN- $\beta$ induced an increase of IFN- $\gamma$ secretion compared to beads only (median 2.8 (2.04.9) vs $1, p=0.049$ ), and addition of the three cytokines induced a very significant increase (median $4.7(1.7-12.1)$ vs $1, \mathrm{p}=0.002$, Dunn's post-test, Fig. 3C).

Therefore, intracellular IFN- $\gamma$ production by the $\mathrm{CD}^{+} \mathrm{T}$ cell clone was induced by cytokines alone (i.e. IFN- $\alpha$ and IFN- $\beta$, perhaps potentiated by TNF- $\alpha$ ), at similar levels as those observed with non-cognate stimulation by HLA-A2- ${ }^{-}$DC incubated with apoptotic H9HIV cells, while intracellular GzB was expressed constitutively. Secretion of IFN- $\gamma$ by $\mathrm{CD}^{+} \mathrm{T}$ cells occurred only upon cognate interaction and was increased by cytokine stimulation.

\section{Blocking type I IFN pathway abolished non-cognate $\mathrm{CD8}^{+} \mathrm{T}$ cell preactivation}

312 To know whether these cytokines were entirely responsible for the non-cognate $\mathrm{T}$ cell

313 activation elicited by pDC, we added a cocktail of three antibodies to neutralize IFN- $\alpha$, TNF-

$314 \alpha$ and the IFN- $\alpha$ and $\beta$ Receptor (IFNAR) in the coculture of pDC with apoptotic H9HIV cells,

$31530 \mathrm{~min}$ before adding the $\mathrm{CD}^{+} \mathrm{T}$ cell clone for $4 \mathrm{~h}$ (Fig. 4). Compared to isotypic controls,

316 these antibodies abolished partly the cognate stimulation by HLA-A2 $2^{+} \mathrm{pDC}$ (median $2.5 \%(-3-$

317 11) vs $12.6 \%(5.7-18.2), n=7$, Wilcoxon $p=0.016)$, and seemed to abolish completely the non-

318 cognate stimulation of the $\mathrm{CD}^{+} \mathrm{T}$ cell clone by HLA-A2 ${ }^{-} \mathrm{pDC}$, when present (median $0.9 \%$

$319(-0.1-2.5)$ vs $1.4 \%(-0.3-6.5) \mathrm{IFN}-\gamma^{+} \mathrm{CD} 8^{+} \mathrm{T}$ cells, respectively, $\mathrm{n}=6$, Wilcoxon $\mathrm{p}=0.13$, not

320 significant; Fig. 4). Blocking TNF- $\alpha$ only $(n=4)$ did not have an effect on IFN- $\gamma$ intracellular

321 production in $\mathrm{CD}^{+} \mathrm{T}$ cell clones, while blocking type I IFN receptor and IFN- $\alpha$ appeared to

322 replicate the effects of using all three blocking antibodies compared to isotype controls (Mann-

323 Whitney $\mathrm{p}=0.04, \mathrm{n}=5$ ). Therefore, IFN $-\alpha$ and IFN- $\beta$ secreted by $\mathrm{pDC}$ in the presence of 324 apoptotic H9HIV cells were indeed responsible for the non-cognate $\mathrm{T}$ cell activation elicited 325 by pDC. 


\section{Discussion}

327 We previously showed that human blood pDC induced HIV-Gag specific, HLA-A2 restricted,

$328 \mathrm{CD}^{+}$T-cell activation and IFN- $\gamma$ secretion through cross-presentation of apoptotic HIV-1-

329 infected cell antigens $(18,21)$. Here we found that although IFN- $\gamma$ secretion was MHC-I

330 dependent, intracellular IFN- $\gamma$ production was only partly MHC-I dependent. By dissociating

331 cognate signals, mimicked by beads without virus, and non-cognate signals, we observed that

332 the non-cognate part of the response was due to IFN- $\alpha$ and IFN- $\beta$, possibly potentialized by

333 TNF- $\alpha$, secreted by $\mathrm{pDC}$ in response to HIV contained in antigen-donor cells. This non-cognate

334 signal also enhanced the cognate response. Thus, $\mathrm{CD} 8^{+} \mathrm{T}$-cells activation induced by cross-

335 presentation of HIV-1 gag from infected cells by pDC was potentiated by non-cognate pre-

336 activation (Fig. 5). This finding questions the dogma that while cytolytic effector molecules

337 such as Granzyme B are expressed continuously in effector and memory T cells, poising them

338 for rapid killing of target cells immediately upon T Cell Receptor (TCR) triggering, IFN- $\gamma$

339 production is tightly regulated, being triggered as very short ON/OFF cycles by engagement

340 of the TCR $(36,37)$. Here, IFN- $\gamma$ secretion was tightly regulated by engagement of the TCR,

341 but intracellular IFN- $\gamma$ production was pre-activated upon type I-IFN-signaling.

342 Conversely to $\mathrm{pDC}, \mathrm{cDC} 1$ and $\mathrm{cDC} 2$ required the addition of TLR ligands for their specific

343 TLRs (either poly-IC for TLR-3 or LPS for TLR4, respectively) to perform cross-presentation.

344 Here, we showed that pDC were already stimulated through detection of HIV contained in

345 antigen-donor cells, and did not require additional stimulation. Comparison between the three

346 DC populations showed that $\mathrm{pDC}$ and $\mathrm{cDC} 1$ were equivalent at inducing $\mathrm{CD}^{+} \mathrm{T}$ cell

347 activation. cDC2 were less effective, even when stimulated by LPS. In our model, MHC-I-

348 independent $\mathrm{CD}^{+} \mathrm{T}$ cell activation was not demonstrated for $\mathrm{cDC}$. Indeed, $\mathrm{cDC}$ did not

349 upregulate CD83 or CCR7 or secrete IFN- $\alpha$ in response to cell-associated HIV, as they lack 
both TLR-7 and 9 (45). This is in agreement with other results on pDC and cDC stimulated with free HIV virions (33)(43).

352 We then analyzed the mechanism responsible for the MHC-I independent activation of CD8 ${ }^{+}$

$353 \mathrm{~T}$ cells in the presence of pDC and apoptotic HIV infected cells. IFN- $\alpha$ as a signal 3 cytokine 354 can activate IFN- $\gamma$ expression by human $\mathrm{CD}^{+} \mathrm{T}$ cells $(34,46)$. IFN- $\alpha$ is also known to be secreted at high levels by human pDC in response to HIV virions, among other cytokines such as IFN- $\beta$, TNF- $\alpha$ or IL-6 $(32,33,43)$. We indeed showed here that cell-associated HIV led to pDC maturation and IFN- $\alpha$ secretion by $\mathrm{pDC}$, but not by $\mathrm{cDC}$. HIV might still potentially stimulate TLR-8 in $\mathrm{cDC} 1$ and $\mathrm{cDC} 2$ and induce not IFN- $\alpha$, but IFN- $\beta$, IL-12 or TNF- $\alpha$ in cDC1 or cDC2 through TLR-8 (47), which might explain the occasional non-cognate stimulation of IFN- $\gamma$ production by the $\mathrm{CD} 8^{+} \mathrm{T}$ cell clone by $\mathrm{cDC} 1$ in one donor in our results (Fig. 1A). Furthermore, we showed that a combination of IFN- $\alpha$, IFN- $\beta$ and TNF- $\alpha$ induced a higher IFN- $\gamma$ intracellular production than medium alone in $\mathrm{CD}^{+} \mathrm{T}$ cell clones. The level detected ( $10 \%$ of IFN- $\gamma^{+}$among $\mathrm{CD} 8^{+} \mathrm{T}$ cells) was in the same range as the MHC-I independent signal observed with HLA-A2- $\mathrm{pDC}$ in the presence of apoptotic HIV infected cells (8.9 to $10 \%)$. This, in addition to the absence of IFN- $\gamma$ production observed with HLA-A2 ${ }^{-} \mathrm{cDC}$ in the presence of H9HIV cells, ruled out a potential additional direct effect of cell-associated HIV-

3671 on the $\mathrm{CD}^{+} \mathrm{T}$ cells, which might have been activated by HIV-1 through TLR-8 (48).

368 Moreover, when these cytokines were neutralized by blocking IFN- $\alpha$ and IFNAR, the

369 percentage of IFN $-\gamma^{+}$cells among $\mathrm{CD}^{+} \mathrm{T}$ cells was either reduced in the case of HLA-A2 ${ }^{+}$ $370 \mathrm{pDC}$ or abolished in the case of HLA-A2 $\mathrm{pDC}$. This total abolition showed that other soluble 371 or cell-associated factors did not seem to contribute to the non-cognate $\mathrm{T}$ cell stimulation by 372 HLA-A2- $\mathrm{pDC}$. The same trend was followed when only blocking IFN- $\alpha$ and IFNAR, but not when blocking TNF- $\alpha$ only. Thus, IFN- $\alpha$ and $-\beta$ stimulation of $\mathrm{CD}^{+} \mathrm{T}$ cells recapitulated the 
374 stimulation of IFN- $\gamma$ intracellular production induced by $\mathrm{pDC}$ independently of MHC-I

375 presentation.

376 In our model, this MHC-I independent $\mathrm{CD} 8^{+} \mathrm{T}$ cell activation mechanism found with $\mathrm{pDC}$ was

377 not demonstrated with $\mathrm{cDC}$. Indeed, cDC did not secrete type I IFN in response to cell378 associated HIV, consistently with their lack of or low expression of TLR-7 and 9 (45). While 379 cDC2 express only low levels of TLR7 and no TLR9 (49), they still express TLR8, which 380 might recognize HIV-1 RNA (50). However, in our experiments, sensing of cell-associated 381 HIV by cDC failed to induce their maturation or secretion of IFN- $\alpha$, consistently with previous 382 work showing no activation, IFN- $\alpha$ nor TNF- $\alpha$ production of conventional DC in the presence 383 of HIV virions $(32,43)$. Even though $\mathrm{cDC}$ were not activated in response to free or cellassociated virus, and did not induce non-cognate $\mathrm{CD} 8^{+} \mathrm{T}$ cell activation, they are activated by type I IFN, which is secreted by pDC after stimulation with either free HIV (43), or cellassociated HIV (Isnard, in preparation). IFN-DC generated in vitro from monocytes stimulated by GM-CSF and IFN- $\alpha$ induce in vivo cross-priming of protein-specific $\mathrm{CD}^{+} \mathrm{T}$ cells against inactivated HIV-1 or HCV NS3 protein more efficiently than DC generated from monocytes stimulated by GM-CSF and IL-4 (51) and protection against HIV-1 infection in SCID-hu mice (52), and IFN- $\alpha$ enhances the capacity of cDC to cross-present HIV-1 and tumor antigens (53).

391 Therefore, in vivo, cDC may act in collaboration with pDC for the cross-presentation of HIV antigens and antiviral activity of $\mathrm{CD}^{+} \mathrm{T}$ cell.

Interestingly, this effect was specific for IFN- $\gamma$ production while Granzyme B production, known to be continuously expressed by cytotoxic and memory CD8 $+\mathrm{T}$ cells, was indeed independent on type I IFN production. IFN- $\gamma$ has strong antiviral effects, but during chronic $\mathrm{HIV}$ infection, it may also participate in $\mathrm{CD}^{+} \mathrm{T}$ cell hyperactivation and exhaustion which correlate with disease progression (54). Hyperactivation has been linked to the persistent type I IFN signature found in this infection (55-57). In line with our results, in vitro IFN- $\alpha$ 
stimulation of $\mathrm{CD}^{+} \mathrm{T}$ cells from chronic HIV-1 infected patients with progressive disease

400 enhanced their production of IFN- $\gamma$, their degranulation, and their HIV-1 suppressive activity

401 (58). In vivo, the effects of IFN- $\alpha$ treatment, induction or inhibition depend on the time and

402 dosage. Before infection of Rhesus macaques, IFN- $\alpha$ treatment prevents infection, but if

403 treatment is extended during SIV infection, it contributes to $\mathrm{CD} 8^{+} \mathrm{T}$ cell activation, type I IFN-

404 desensitization and progression to AIDS (59). During chronic infection, IFN- $\alpha$ treatment

405 decreases viral loads transiently (60) and potentially proviral loads (61), and increases $\mathrm{CD}^{+} \mathrm{T}$

406 cell activation (62). Howevever, chronic IFN- $\alpha$ administration in vivo can induce monocyte-

407 derived suppressor cells and limit $\mathrm{CD}^{+} \mathrm{T}$-cell antiviral functions (63). Antagonization of IFN-

$408 \alpha$ signaling at the onset of infection reduces $\mathrm{T}$ cell activation and exhaustion, but accelerates

409 progression to AIDS $(59,64)$, whereas long-term antagonization during chronic SIV infection,

410 either treated by cART or not, reduces ISG expression without increasing viral replication (65).

411 Hence our results are in line with such findings, showing that type I IFN participate in immune

412 activation by increasing $\mathrm{CD}^{+} \mathrm{T}$-cell activation during HIV/SIV infection.

413 As a conclusion, in the context of virus-infected cells, pDC can trigger intracellular IFN- $\gamma$

414 protein production and accumulation in $\mathrm{CD}^{+} \mathrm{T}$ cells, even when they do not present the

415 cognate peptide (Fig. 5A). This potentializes the secretion of IFN- $\gamma$ once $\mathrm{CD}^{+} \mathrm{T}$ cells

416 encounter antigen-presenting cells with their cognate MHC-viral epitope complex (Fig. 5B).

417 This finding may help to understand how to modulate and channel type I IFN production so

418 that it leads to IFN- $\gamma$ release only toward infected cells, improving elimination of infected or

419 tumor cells.

420

\section{Acknowledgments}

422 We greatly acknowledge Dr Bénédicte Manoury for critical reading of the manuscript, Drs 


\section{References}

1. Borrow, P., H. Lewicki, B. Hahn, G. Shaw, and M. Oldstone. 1994. Virus-specific CD8+ cytotoxic T-lymphocyte activity associated with control of viremia in primary human immunodeficiency virus type 1 infection. Journal of virology 68: 6103-6110.

2. Koup, R. A., J. T. Safrit, Y. Cao, C. A. Andrews, G. M. Leod, W. Borkowsky, C. Farthing, and D. D. Ho. 1994. Temporal association of cellular immune responses with the initial control of viremia in primary human immunodeficiency virus type 1 syndrome. J. Virol. 68: 4650-4655.

3. Musey, L., J. Hughes, T. Schacker, T. Shea, L. Corey, and J. McElrath. 1997. Cytotoxic T cell responses, viral load and disease progression in early HIV-1 infection. New Engl J Med 337: 1267-1274.

4. Ogg, G., X. Jin, S. Bonhoeffer, P. Dunbar, M. Nowak, S. Monard, J. Segal, Y. Cao, S. RowlandJones, V. Cerundolo, A. Hurley, M. Markowitz, D. Ho, D. Nixon, and A. McMichael. 1998. Quantitation of HIV-1-specific cytotoxic T lymphocytes and plasma load of viral RNA. Science 279: 2103-2106.

5. Rinaldo, C., X. Huang, Z. Fan, M. Ding, L. Beltz, A. Logar, D. Panicali, G. Mazzara, J. Liebmann, and M. Cottrill. 1995. High levels of anti-human immunodeficiency virus type 1 (HIV-1) memory cytotoxic T-lymphocyte activity and low viral load are associated with lack of disease in HIV-1-infected long-term nonprogressors. Journal of virology 69: 5838-5842.

6. Jin, X., D. Bauer, S. Tuttleton, S. Lewin, A. Gettie, J. Blanchard, C. Irwin, J. Safrit, J. Mittler, L. Weinberger, L. Kostrikis, L. Zhang, A. Perelson, and D. Ho. 1999. Dramatic rise in plasma viremia after CD8+ T cell depletion in SIV-infected macaques. The Journal of experimental medicine 189: 991-998.

7. Matano, T., R. Shibata, C. Siemon, M. Connors, H. Lane, and M. Martin. 1998. Administration of an anti-CD8 monoclonal antibody interferes with the clearance of chimeric simian/human immunodeficiency virus during primary infections of rhesus macaques. Journal of virology 72 : 164-169.

8. Schmitz, J. E., M. J. Kuroda, S. Santra, V. G. Sasseville, M. A. Simon, M. A. Lifton, P. Racz, K. Tenner-Racz, M. Dalesandro, B. J. Scallon, J. Ghrayeb, M. A. Forman, D. C. Montefiori, E. P. Rieber, N. L. Letvin, and K. A. Reimann. 1999. Control of viremia in simian immunodeficiency virus infection by CD8+ lymphocytes. Science 283: 857-860.

9. Rock, K. L., E. Reits, and J. Neefjes. 2016. Present Yourself! By MHC Class I and MHC Class II Molecules. Trends in immunology 37: 724-737.

10. Cruz, F. M., J. D. Colbert, E. Merino, B. A. Kriegsman, and K. L. Rock. 2017. The Biology and Underlying Mechanisms of Cross-Presentation of Exogenous Antigens on MHC-I Molecules. Annual review of immunology 35: 149-176. 
11. Joffre, O. P., E. Segura, A. Savina, and S. Amigorena. 2012. Cross-presentation by dendritic cells. Nature reviews. Immunology 12: 557-569.

12. Bloch, N., M. O'Brien, T. D. Norton, S. B. Polsky, N. Bhardwaj, and N. R. Landau. 2013. HIV Type 1 Infection of Plasmacytoid and Myeloid Dendritic Cells Is Restricted by High Levels of SAMHD1 and Cannot be Counteracted by Vpx. AIDS research and human retroviruses.

13. Guermonprez, P., L. Saveanu, M. Kleijmeer, J. Davoust, P. Van Endert, and S. Amigorena. 2003. ER-phagosome fusion defines an MHC class I cross-presentation compartment in dendritic cells. Nature 425: 397-402.

14. Houde, M., S. Bertholet, E. Gagnon, S. Brunet, G. Goyette, A. Laplante, M. F. Princiotta, P. Thibault, D. Sacks, and M. Desjardins. 2003. Phagosomes are competent organelles for antigen cross-presentation. Nature 425: 402-406.

15. Sengupta, D., M. Graham, X. Liu, and P. Cresswell. 2019. Proteasomal degradation within endocytic organelles mediates antigen cross-presentation. The EMBO journal: e99266.

16. Iyoda, T., S. Shimoyama, K. Liu, Y. Omatsu, Y. Akiyama, Y. Maeda, K. Takahara, R. M. Steinman, and K. Inaba. 2002. The CD8+ dendritic cell subset selectively endocytoses dying cells in culture and in vivo. The Journal of experimental medicine 195: 1289-1302.

17. Bachem, A., S. Guttler, E. Hartung, F. Ebstein, M. Schaefer, A. Tannert, A. Salama, K. Movassaghi, C. Opitz, H. W. Mages, V. Henn, P. M. Kloetzel, S. Gurka, and R. A. Kroczek. 2010. Superior antigen cross-presentation and XCR1 expression define human CD11c+CD141+ cells as homologues of mouse CD8+ dendritic cells. The Journal of experimental medicine 207: 1273-1281.

18. Crozat, K., R. Guiton, V. Contreras, V. Feuillet, C. A. Dutertre, E. Ventre, T. P. Vu Manh, T. Baranek, A. K. Storset, J. Marvel, P. Boudinot, A. Hosmalin, I. Schwartz-Cornil, and M. Dalod. 2010. The XC chemokine receptor 1 is a conserved selective marker of mammalian cells homologous to mouse CD8\{alpha\}+ dendritic cells. The Journal of experimental medicine 207: 1283-1292.

19. Jongbloed, S. L., A. J. Kassianos, K. J. McDonald, G. J. Clark, X. Ju, C. E. Angel, C. J. Chen, P. R. Dunbar, R. B. Wadley, V. Jeet, A. J. Vulink, D. N. Hart, and K. J. Radford. 2010. Human CD141+ (BDCA-3)+ dendritic cells (DCs) represent a unique myeloid DC subset that cross-presents necrotic cell antigens. The Journal of experimental medicine 207: 1247-1260.

20. Poulin, L. F., M. Salio, E. Griessinger, F. Anjos-Afonso, L. Craciun, J. L. Chen, A. M. Keller, O. Joffre, S. Zelenay, E. Nye, A. Le Moine, F. Faure, V. Donckier, D. Sancho, V. Cerundolo, D. Bonnet, and C. Reis e Sousa. 2010. Characterization of human DNGR-1+ BDCA3+ leukocytes as putative equivalents of mouse CD8alpha+ dendritic cells. The Journal of experimental medicine 207: 1261-1271.

21. Hoeffel, G., A. C. Ripoche, D. Matheoud, M. Gannagé, S. Louis, M. Nascimbeni, N. Escriou, F. Heshmati, S. Caillat-Zucman, N. Casartelli, O. Schwartz, J. G. Guillet, H. de la Salle, D. Hanau, A. Hosmalin, and C. Marañon. 2007. Antigen cross-presentation by Plasmacytoid Dendritic Cells. Immunity 27: 481-492

22. Segura, E., M. Durand, and S. Amigorena. 2013. Similar antigen cross-presentation capacity and phagocytic functions in all freshly isolated human lymphoid organ-resident dendritic cells. The Journal of experimental medicine 210: 1035-1047.

23. Tel, J., G. Schreibelt, S. P. Sittig, T. S. Mathan, S. I. Buschow, L. J. Cruz, A. J. Lambeck, C. G. Figdor, and I. J. de Vries. 2013. Human plasmacytoid dendritic cells efficiently cross-present exogenous Ags to CD8+ T cells despite lower Ag uptake than myeloid dendritic cell subsets. Blood 121: 459-467.

24. Di Pucchio, T., B. Chatterjee, A. Smed-Sorensen, S. Clayton, A. Palazzo, M. Montes, Y. Xue, I. Mellman, J. Banchereau, and J. E. Connolly. 2008. Direct proteasome-independent crosspresentation of viral antigen by plasmacytoid dendritic cells on major histocompatibility complex class I. Nature immunology 9: 551-557. 
25. Klechevsky, E., A. L. Flamar, Y. Cao, J. P. Blanck, M. Liu, A. O'Bar, O. Agouna-Deciat, P. Klucar, L. Thompson-Snipes, S. Zurawski, Y. Reiter, A. K. Palucka, G. Zurawski, and J. Banchereau. 2010. Cross-priming CD8+ T cells by targeting antigens to human dendritic cells through DCIR. Blood 116: 1685-1697.

26. Lui, G., O. Manches, J. Angel, J. P. Molens, L. Chaperot, and J. Plumas. 2009. Plasmacytoid dendritic cells capture and cross-present viral antigens from influenza-virus exposed cells. PloS one 4: e7111.

27. Mittag, D., A. I. Proietto, T. Loudovaris, S. I. Mannering, D. Vremec, K. Shortman, L. Wu, and L. C. Harrison. 2011. Human dendritic cell subsets from spleen and blood are similar in phenotype and function but modified by donor health status. Journal of immunology 186: 6207-6217.

28. Aspord, C., C. Leloup, S. Reche, and J. Plumas. 2014. pDCs efficiently process synthetic long peptides to induce functional virus- and tumour-specific T-cell responses. European journal of immunology 44: 2880-2892.

29. Guillerme, J. B., N. Boisgerault, D. Roulois, J. Menager, C. Combredet, F. Tangy, J. F. Fonteneau, and M. Grégoire. 2013. Measles Virus Vaccine-Infected Tumor Cells Induce Tumor Antigen Cross-Presentation by Human Plasmacytoid Dendritic Cells. Clin Cancer Res 19: 1147-1158.

30. Mouries, J., G. Moron, G. Schlecht, N. Escriou, G. Dadaglio, and C. Leclerc. 2008. Plasmacytoid dendritic cells efficiently cross-prime naive T cells in vivo after TLR activation. Blood 112: 37133722.

31. Tanaka, T., T. Kajiwara, G. Kutomi, T. Kurotaki, K. Saito, T. Kanaseki, T. Tsukahara, Y. Hirohashi, T. Torigoe, K. Hirata, Y. Okamoto, N. Sato, and Y. Tamura. 2015. CpG-A stimulates Hsp72 secretion from plasmacytoid dendritic cells, facilitating cross-presentation. Immunology letters 167: 34-40.

32. Beignon, A. S., K. McKenna, M. Skoberne, O. Manches, I. Dasilva, D. G. Kavanagh, M. Larsson, R. J. Gorelick, J. D. Lifson, and N. Bhardwaj. 2005. Endocytosis of HIV-1 activates plasmacytoid dendritic cells via Toll-like receptor- viral RNA interactions. The Journal of clinical investigation 115: 3265-3275.

33. Smith, N., P. O. Vidalain, S. Nisole, and J. P. Herbeuval. 2016. An efficient method for gene silencing in human primary plasmacytoid dendritic cells: silencing of the TLR7/IRF-7 pathway as a proof of concept. Scientific reports 6: 29891.

34. Hervas-Stubbs, S., U. Mancheno, J. I. Riezu-Boj, A. Larraga, M. C. Ochoa, D. Alignani, C. Alfaro, A. Morales-Kastresana, I. Gonzalez, E. Larrea, H. Pircher, A. Le Bon, J. M. Lopez-Picazo, S. Martin-Algarra, J. Prieto, and I. Melero. 2012. CD8 T cell priming in the presence of IFN-alpha renders CTLS with improved responsiveness to homeostatic cytokines and recall antigens: important traits for adoptive T cell therapy. Journal of immunology 189: 3299-3310.

35. Westdorp, H., J. H. A. Creemers, I. M. van Oort, G. Schreibelt, M. A. J. Gorris, N. Mehra, M. Simons, A. L. de Goede, M. M. van Rossum, A. J. Croockewit, C. G. Figdor, J. A. Witjes, E. Aarntzen, R. D. M. Mus, M. Bruning, K. Petry, M. Gotthardt, J. O. Barentsz, I. J. M. de Vries, and W. R. Gerritsen. 2019. Blood-derived dendritic cell vaccinations induce immune responses that correlate with clinical outcome in patients with chemo-naive castration-resistant prostate cancer. J Immunother Cancer 7: 302.

36. Corbin, G. A., and J. T. Harty. 2005. T cells undergo rapid ON/OFF but not ON/OFF/ON cycling of cytokine production in response to antigen. J Immunol 174: 718-726.

37. Slifka, M. K., F. Rodriguez, and J. L. Whitton. 1999. Rapid on/off cycling of cytokine production by virus-specific CD8+ T cells. Nature 401: 76-79.

38. Isnard, S., E. Hatton, J. Guillerme, and A. Hosmalin. 2020. Monitoring antigen crosspresentation with human dendritic cells purified from the blood. In Tumor immunology and immunotherapy - Integrated methods. L. Galluzzi, and N. Rudqvist, eds. Elsevier, Inc., Meth Enzymol 635: 283-305. 
39. Popovic, M., E. Read-Connole, and R. C. Gallo. 1984. T4 positive human neoplastic cell lines susceptible to and permissive for HTLV-III. Lancet 2: 1472-1473.

40. Popovic, M., M. G. Sarngadharan, E. Read, and R. C. Gallo. 1984. Detection, isolation, and continuous production of cytopathic retroviruses (HTLV-III) from patients with AIDS and preAIDS. Science 224: 497-500.

41. Tsomides, T. J., A. Aldovini, R. P. Johnson, B. D. Walker, R. A. Young, and H. N. Eisen. 1994. Naturally processed viral peptides recognized by cytotoxic $T$ lymphocytes on cells chronically infected by human immunodeficiency virus type 1 . The Journal of experimental medicine 180 : 1283-1293.

42. Fonteneau, J. F., M. Larsson, S. Somersan, C. Sanders, C. Munz, W. W. Kwok, N. Bhardwaj, and F. Jotereau. 2001. Generation of high quantities of viral and tumor-specific human CD4+ and CD8+ T-cell clones using peptide pulsed mature dendritic cells. J Immunol Methods 258: 111126.

43. Fonteneau, J. F., M. Larsson, A. S. Beignon, K. McKenna, I. Dasilva, A. Amara, Y. J. Liu, J. D. Lifson, D. R. Littman, and N. Bhardwaj. 2004. Human immunodeficiency virus type 1 activates plasmacytoid dendritic cells and concomitantly induces the bystander maturation of myeloid dendritic cells. Journal of virology 78: 5223-5232.

44. June, C. H., J. A. Ledbetter, M. M. Gillespie, T. Lindsten, and C. B. Thompson. 1987. T-cell proliferation involving the $\mathrm{CD} 28$ pathway is associated with cyclosporine-resistant interleukin 2 gene expression. Mol Cell Biol 7: 4472-4481.

45. Lindstedt, M., K. Lundberg, and C. A. Borrebaeck. 2005. Gene family clustering identifies functionally associated subsets of human in vivo blood and tonsillar dendritic cells. J Immunol 175: 4839-4846.

46. Hervas-Stubbs, S., J. I. Riezu-Boj, I. Gonzalez, U. Mancheno, J. Dubrot, A. Azpilicueta, I. Gabari, A. Palazon, A. Aranguren, J. Ruiz, J. Prieto, E. Larrea, and I. Melero. 2010. Effects of IFN-alpha as a signal-3 cytokine on human naive and antigen-experienced CD8(+) T cells. European journal of immunology 40: 3389-3402.

47. Hemont, C., A. Neel, M. Heslan, C. Braudeau, and R. Josien. 2013. Human blood mDC subsets exhibit distinct TLR repertoire and responsiveness. Journal of leukocyte biology 93: 599-609.

48. Meas, H. Z., M. Haug, M. S. Beckwith, C. Louet, L. Ryan, Z. Hu, J. Landskron, S. A. Nordbo, K. Tasken, H. Yin, J. K. Damas, and T. H. Flo. 2020. Sensing of HIV-1 by TLR8 activates human T cells and reverses latency. Nature communications 11: 147.

49. Kreutz, M., G. Bakdash, Y. Dolen, A. E. Skold, M. A. van Hout-Kuijer, I. J. de Vries, and C. G. Figdor. 2015. Type I IFN-mediated synergistic activation of mouse and human DC subsets by TLR agonists. Eur J Immunol 45: 2798-2809.

50. Heil, F., H. Hemmi, H. Hochrein, F. Ampenberger, C. Kirschning, S. Akira, G. Lipford, H. Wagner, and S. Bauer. 2004. Species-specific recognition of single-stranded RNA via toll-like receptor 7 and 8. Science 303: 1526-1529.

51. Lapenta, C., S. M. Santini, M. Spada, S. Donati, F. Urbani, D. Accapezzato, D. Franceschini, M. Andreotti, V. Barnaba, and F. Belardelli. 2006. IFN- $\alpha$-conditioned dendritic cells are highly efficient in inducing cross-priming CD8+ T cells against exogenous viral antigens. European journal of immunology 36: 2046-2060.

52. Lapenta, C., S. M. Santini, M. Logozzi, M. Spada, M. Andreotti, T. Di Pucchio, S. Parlato, and F. Belardelli. 2003. Potent immune response against HIV-1 and protection from virus challenge in hu-PBL-SCID mice immunized with inactivated virus-pulsed dendritic cells generated in the presence of IFN-alpha. The Journal of experimental medicine 198: 361-367.

53. Schiavoni, G., F. Mattei, and L. Gabriele. 2013. Type I Interferons as Stimulators of DCMediated Cross-Priming: Impact on Anti-Tumor Response. Frontiers in immunology 4: 483.

54. Day, C. L., D. E. Kaufmann, P. Kiepiela, J. A. Brown, E. S. Moodley, S. Reddy, E. W. Mackey, J. D. Miller, A. J. Leslie, C. DePierres, Z. Mncube, J. Duraiswamy, B. Zhu, Q. Eichbaum, M. Altfeld, E. J. Wherry, H. M. Coovadia, P. J. Goulder, P. Klenerman, R. Ahmed, G. J. Freeman, and B. D. 
Walker. 2006. PD-1 expression on HIV-specific T cells is associated with T-cell exhaustion and disease progression. Nature 443: 350-354.

55. Hardy, G. A., S. Sieg, B. Rodriguez, D. Anthony, R. Asaad, W. Jiang, J. Mudd, T. Schacker, N. T. Funderburg, H. A. Pilch-Cooper, R. Debernardo, R. L. Rabin, M. M. Lederman, and C. V. Harding. 2013. Interferon-alpha is the primary plasma type-I IFN in HIV-1 infection and correlates with immune activation and disease markers. PloS one 8: e56527.

56. Jacquelin, B., V. Mayau, B. Targat, A. S. Liovat, D. Kunkel, G. Petitjean, M. A. Dillies, P. Roques, C. Butor, G. Silvestri, L. D. Giavedoni, P. Lebon, F. Barre-Sinoussi, A. Benecke, and M. C. MullerTrutwin. 2009. Nonpathogenic SIV infection of African green monkeys induces a strong but rapidly controlled type I IFN response. The Journal of clinical investigation 119: 3544-3555.

57. Rotger, M., J. Dalmau, A. Rauch, P. McLaren, S. E. Bosinger, R. Martinez, N. G. Sandler, A. Roque, J. Liebner, M. Battegay, E. Bernasconi, P. Descombes, I. Erkizia, J. Fellay, B. Hirschel, J. M. Miro, E. Palou, M. Hoffmann, M. Massanella, J. Blanco, M. Woods, H. F. Gunthard, P. de Bakker, D. C. Douek, G. Silvestri, J. Martinez-Picado, and A. Telenti. 2011. Comparative transcriptomics of extreme phenotypes of human HIV-1 infection and SIV infection in sooty mangabey and rhesus macaque. J Clin Invest 121: 2391-2400.

58. Kwaa, A. K. R., C. A. G. Talana, and J. N. Blankson. 2019. Interferon Alpha Enhances NK Cell Function and the Suppressive Capacity of HIV-Specific CD8(+) T Cells. Journal of virology 93.

59. Sandler, N. G., S. E. Bosinger, J. D. Estes, R. T. Zhu, G. K. Tharp, E. Boritz, D. Levin, S. Wijeyesinghe, K. N. Makamdop, G. Q. del Prete, B. J. Hill, J. K. Timmer, E. Reiss, G. Yarden, S. Darko, E. Contijoch, J. P. Todd, G. Silvestri, M. Nason, R. B. Norgren, Jr., B. F. Keele, S. Rao, J. A. Langer, J. D. Lifson, G. Schreiber, and D. C. Douek. 2014. Type I interferon responses in rhesus macaques prevent SIV infection and slow disease progression. Nature 511: 601-605.

60. Adalid-Peralta, L., V. Godot, C. Colin, R. Krzysiek, T. Tran, P. Poignard, A. Venet, A. Hosmalin, P. Lebon, C. Rouzioux, G. Chene, D. Emilie, and A. S. G. Interprim. 2008. Stimulation of the primary anti-HIV antibody response by IFN-alpha in patients with acute HIV-1 infection. $J$ Leukoc Biol 83: 1060-1067.

61. Azzoni, L., A. S. Foulkes, E. Papasavvas, A. M. Mexas, K. M. Lynn, K. Mounzer, P. Tebas, J. M. Jacobson, I. Frank, M. P. Busch, S. G. Deeks, M. Carrington, U. O'Doherty, J. Kostman, and L. J. Montaner. 2013. Pegylated Interferon alfa-2a monotherapy results in suppression of HIV type 1 replication and decreased cell-associated HIV DNA integration. The Journal of infectious diseases 207: 213-222.

62. Manion, M., B. Rodriguez, K. Medvik, G. Hardy, C. V. Harding, R. T. Schooley, R. Pollard, D. Asmuth, R. Murphy, E. Barker, K. E. Brady, A. Landay, N. Funderburg, S. F. Sieg, and M. M. Lederman. 2012. Interferon-alpha administration enhances CD8+ T cell activation in HIV infection. PLoS One 7: e30306.

63. Taleb, K., C. Auffray, P. Villefroy, A. Pereira, A. Hosmalin, M. Gaudry, and A. Le Bon. 2017. Chronic Type I IFN Is Sufficient To Promote Immunosuppression through Accumulation of Myeloid-Derived Suppressor Cells. Journal of immunology 198: 1156-1163.

64. Carnathan, D., B. Lawson, J. Yu, K. Patel, J. M. Billingsley, G. K. Tharp, O. M. Delmas, R. Dawoud, P. Wilkinson, C. Nicolette, M. J. Cameron, R. P. Sekaly, S. E. Bosinger, G. Silvestri, and T. H. Vanderford. 2018. Reduced Chronic Lymphocyte Activation following Interferon Alpha Blockade during the Acute Phase of Simian Immunodeficiency Virus Infection in Rhesus Macaques. Journal of virology 92.

65. Nganou-Makamdop, K., J. M. Billingsley, Z. Yaffe, G. O'Connor, G. K. Tharp, A. Ransier, F. Laboune, R. Matus-Nicodemos, A. Lerner, L. Gharu, J. M. Robertson, M. L. Ford, M. Schlapschy, N. Kuhn, A. Lensch, J. Lifson, M. Nason, A. Skerra, G. Schreiber, S. E. Bosinger, and D. C. Douek. 2018. Type I IFN signaling blockade by a PASylated antagonist during chronic SIV infection suppresses specific inflammatory pathways but does not alter $\mathrm{T}$ cell activation or virus replication. PLoS pathogens 14: e1007246. 
66. Starcich, B. R., B. H. Hahn, G. M. Shaw, P. D. McNeely, S. Modrow, H. Wolf, E. S. Parks, W. P. Parks, S. F. Josephs, R. C. Gallo, and F. Wong-Staal. 1986. Identification and characterization of conserved and variable regions in the envelope gene of HTLV-III/LAV, the retrovirus of AIDS. Cell 45: 637-648.

\section{Author contributions}

SI and EXH performed, analyzed and interpreted most experiments and wrote the manuscript. MI and JBG participated in experiment setup, design analyses and interpretation and critically reviewed the manuscript. AH designed the study, oversaw and participated in experiments and analyses, interpreted the data and wrote the manuscript. All authors approved the final version of this manuscript.

\section{Competing interest}

The authors declare no conflict of interest.

\section{Footnotes}

This study was funded by the Association pour la Recherche sur le Cancer (ARC), the Ligue de recherche contre le Cancer-Ile-de-France, the French Government's Investissement d'Avenir program, Laboratoires d'Excellence "Integrative Biology of Emerging Infectious Diseases" (ANR-10-LABX-62-IBEID), the Agence Nationale de Recherche contre le Sida et les Hépatites Virales (ANRS), the Institut National de la Santé et de la Recherche Médicale (INSERM), the National Center for Scientific Research (CNRS) and Université Paris Descartes Sorbonne Paris Cité. SI and EXH received PhD studentships from Université Paris Descartes Sorbonne Paris Cité, MI from the Società Italiana di Malattie Infettive e Tropicali (SIMIT), ANRS and the ANR, and JBG a fellowship from the ANRS.

${ }^{2}$ Current address : Research Institute of the McGill University Health Centre, Montreal, Qc, Canada

${ }^{3}$ Current address : Contributed equally to this work.

${ }^{4}$ Current address : Tor Vergata University of Rome, Department of System Medicine, Rome, Italy 
696 infected apoptotic cells was MHC-I restricted, whereas IFN- $\gamma$ intracellular

697 production was only partly MHC-I restricted

698 Purified HLA-A2 ${ }^{+}$or HLA-A2 ${ }^{-}$pDC, $\mathrm{cDC} 1$ or $\mathrm{cDC} 2$ were cultured overnight with apoptotic

699 H9 cells infected (H9HIV, magenta) or not (H9, green) by HIV-1 $1_{\text {lai, }}$, in the presence of 700 saquinavir and survival factors (IL-3 for $\mathrm{pDC}$, GM-CSF for $\mathrm{cDC}$ ). Conventional $\mathrm{DC}_{1}$ were 701 stimulated with Poly:IC and cDC2 with LPS. Anti-Gag $77-85$ cloned CD8 ${ }^{+} \mathrm{T}$ cell were then added 702 and IFN- $\gamma$ secretion or intracellular production analyzed. A. IFN- $\boldsymbol{\gamma}$ secretion was measured by

703 ELISA after $16 \mathrm{~h}$ incubation. B. IFN- $\gamma$ intracellular production was tested after $4 \mathrm{~h}$ incubation 704 in the presence of BFA, cells were then stained with live/dead and labeled for CD3, CD8, 705 CD1c, CD141, CD123 and HLA-A2, and intracellularly for IFN- $\gamma$, then the percentages of 706 IFN- $\gamma^{+}$cells among $\mathrm{CD}^{+} \mathrm{T}$ cells were analyzed by flow cytometry (38). Wilcoxon test 707 between H9 and H9HIV cells, Mann-Whitney test (italics) between HLA-A2 ${ }^{+}$(pDC A: n=15, 708 B: $n=12$; $c$ DC1 A: $n=8$ with PIC, $n=2$ without PIC, B: $n=6$; cDC2 A: $n=14$ with LPS, $n=5$ 709 without LPS, B: $\mathrm{n}=11$ ) and HLA-A2- donors (pDC A: $\mathrm{n}=9, \mathrm{~B}: \mathrm{n}=10$; $\mathrm{cDC} 1 \mathrm{~A}: \mathrm{n}=4, \mathrm{~B}: \mathrm{n}=4$; 710 cDC2 A: n=6, B: n=9), Mann-Whitney tests (italics) between DC populations.

712 Fig. 2: pDC, not cDC, matured and produced IFN- $\alpha$ in the presence of apoptotic $713 \quad$ HIV-infected cells

714 FACS-purified $\mathrm{pDC}, \mathrm{cDC} 1$ and $\mathrm{cDC} 2$ were incubated overnight with apoptotic H9 or H9HIV

715 cells in the presence of survival factors. A. Maturation. Purified DC, either alone (left) or 716 combined (right), were labelled with anti-CCR7 and -CD83 antibodies and analyzed by flow 
cytometry. One experiment representative out of 3 for $\mathrm{pDC}$ and $\mathrm{cDC} 2$, and of 2 for $\mathrm{cDC} 1$ is shown. B. IFN- $\boldsymbol{\alpha}$ secretion. pDC, cDC1 stimulated with Poly:IC and cDC2 stimulated with LPS were incubated for $16 \mathrm{~h}$ in the presence of H9 (green) or H9HIV (magenta) cells. IFN- $\alpha$ secretion was measured in the supernatants by ELISA. $p D C n=10, c D C 1 n=4, c D C 2 n=10$. Data are shown with medians. Wilcoxon test for comparison of $\mathrm{pDC}+\mathrm{H} 9 \mathrm{HIV}$ and $\mathrm{pDC}+\mathrm{H} 9$.

intracellular production in $\mathrm{CD8}^{+} \mathrm{T}$ cells and IFN- $\gamma$ secretion upon cognate interaction.

A. Intracellular IFN- $\gamma$ production in response to cytokines alone. Cloned $\mathrm{CD}^{+} \mathrm{T}$ cells were stimulated or not for $4 \mathrm{~h}$ with IFN- $\alpha_{2}$, IFN- $\beta$ or TNF- $\alpha$ alone or in combination as indicated. Intracellular IFN- $\gamma$ production was analyzed by flow cytometry $(n=3)$. Data are shown as medians with interquartile ranges. Statistical analysis by Kruskal-Wallis followed by Cloned CD8 ${ }^{+}$T cells were stimulated with IFN- $\alpha$, IFN- $\beta$ and TNF- $\alpha$ (Cytokines), or not (NS),

732 for $4 \mathrm{~h}$. The cells were then fixed and permeabilized, then labeled with anti-CD3, anti-

733 Granzyme B and anti-IFN- $\gamma$ antibodies, and with DAPI. They were analyzed by confocal microscopy. IFN- $\gamma$ is shown in red, Granzyme B in green, CD3 in grey and DAPI-stained DNA in blue. NS: image representative of $18 / 18$ cells, Cytokines: image representative of 28/60 cells positive for IFN- $\gamma$. All cells expressed Granzyme B regardless of stimulation. C. IFN- $\gamma$ secretion in response to cognate interaction is potentiated by cytokines Cloned $\mathrm{CD} 8^{+} \mathrm{T}$ cells were stimulated for $4 \mathrm{~h}$ with IFN- $\alpha_{2}$, IFN- $\beta$ or TNF- $\alpha$, alone or in combination as described in the figure. When indicated, anti-CD3 anti-CD28 coated beads were added for $4 \mathrm{~h}$. IFN- $\gamma$ 
741 only condition ( $\mathrm{n}=5$ or 6 depending on stimulation conditions). Data are shown as medians

742 with interquartile ranges. Medium-only and cytokines-only conditions did not induce IFN- $\gamma$

743 secretion and were not taken into account for the statistical tests. Statistical analysis by

744 Kruskal-Wallis test followed by Dunn's multiple comparison post-test.

Fig. 4: Antibodies blocking IFN- $\alpha$ and IFNAR abolished INF- $\gamma$ intracellular

$\mathrm{HLA}_{-} \mathrm{A}^{+}(\mathrm{n}=7)$ or HLA-A2- $(\mathrm{n}=6)$ purified $\mathrm{pDC}$ were cultured overnight with apoptotic H9 (green) or H9HIV (magenta) cells in the presence of IL-3, then incubated with either neutralizing antibodies targeting IFN- $\alpha$ and IFN- $\alpha$ receptor only, TNF- $\alpha$ only or all three (10 $\mu \mathrm{g} / \mathrm{mL}$ each) or isotype controls at the same concentrations (Isotypes), before cloned anti$\operatorname{Gag}_{77-85} \mathrm{CD}^{+} \mathrm{T}$ cells were added. After $4 \mathrm{~h}$ in the presence of BFA, cells were labelled as in

753 Fig. 1B and analyzed by flow cytometry.

Fig. 5: Model. Cell associated HIV cross-presentation by pDC is potentiated by non-cognate $\mathrm{CD8}^{+} \mathrm{T}$ cell preactivation

757 H9 cells infected with HIV induce type I IFN production by pDC

758 Type I IFN induces IFN- $\gamma$ intracellular production in $\mathrm{CD}^{+} \mathrm{T}$ cells

759 pDC cross-present MHC-restricted HIV-gag antigen to specific CD8 ${ }^{+} \mathrm{T}$ cells

760 IFN- $\gamma$ secretion by $\mathrm{CD}^{+} \mathrm{T}$ cells is potentiated by former stimulation by type I IFN, but occurs

761 only in the case of cognate interaction with pDC 
Fig. 1

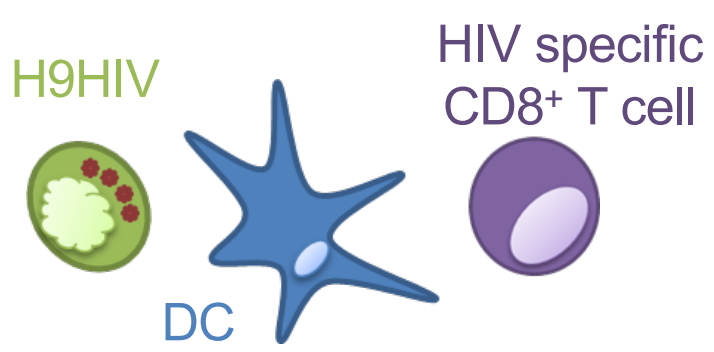

A Secretion $\quad 0.008$

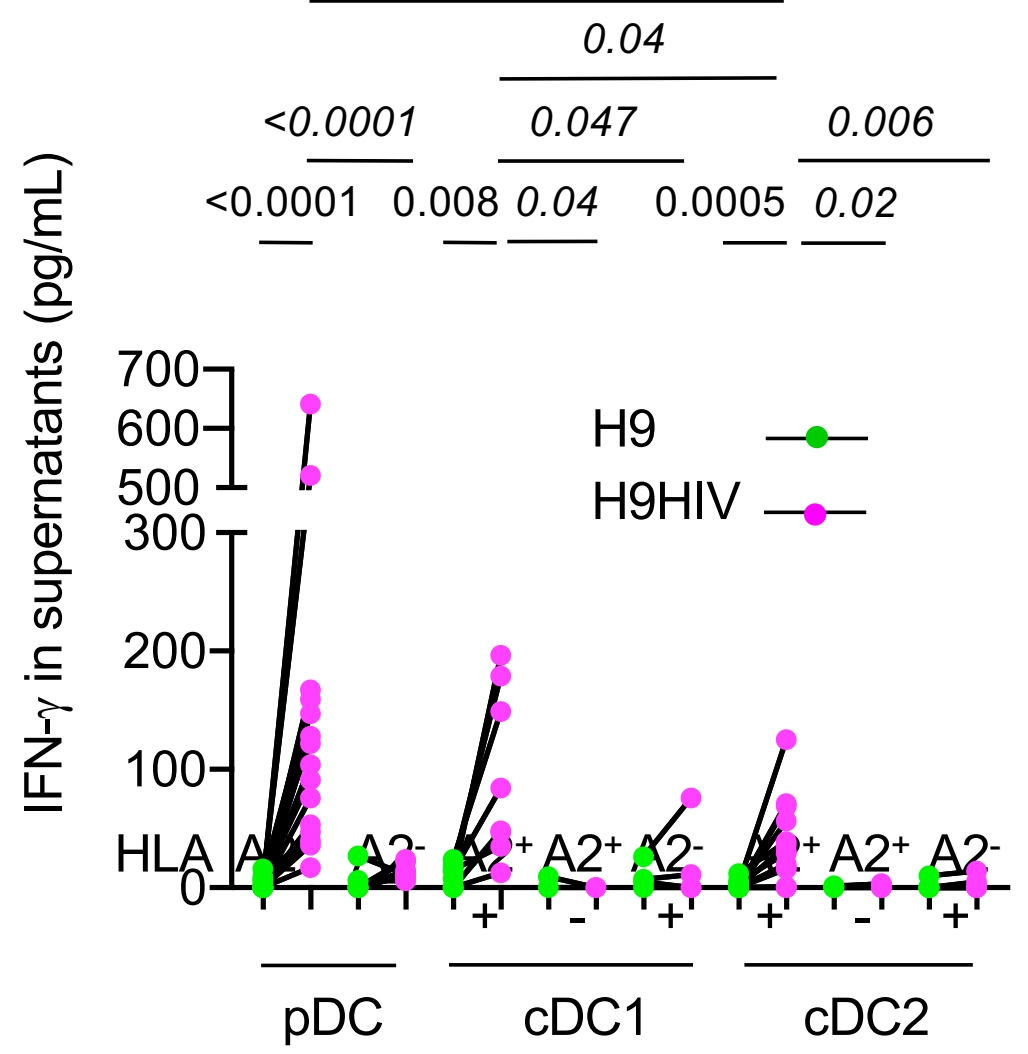

Fig. 1: IFN- $\gamma$ secretion by $\mathrm{CD}^{+} \mathrm{T}$ cells in the presence of $\mathrm{pDC}$ incubated with HIV-infected apoptotic cells was MHC-I-restricted, whereas IFN- $\gamma$ intracellular production was only partly MHC-I-restricted

Purified HLA-A2 ${ }^{+}$or HLA-A2- $\mathrm{pDC}$, $\mathrm{cDC} 1$ or $\mathrm{CDC} 2$ were cultured overnight with apoptotic H9 cells infected (H9HIV, magenta) or not (H9, green) by HIV-1 $1_{\text {lai }}$, in the presence of saquinavir and survival factors (IL-3 for $\mathrm{pDC}, \mathrm{GM}-\mathrm{CSF}$ for $\mathrm{cDC})$. Conventional DC1 were stimulated $(+)$ or not (-) with Poly:IC and cDC2 were stimulated $(+)$ or not (-) with LPS. Anti-Gag ${ }_{77-85}$ cloned $\mathrm{CD}^{+} \mathrm{T}$ cells were then added and IFN- $\gamma$ secretion or intracellular production tested. A. IFN- $\gamma$ secretion was measured by ELISA after $16 \mathrm{~h}$ incubation. B. IFN- $\gamma$ intracellular production was tested after $4 \mathrm{~h}$ incubation in the presence of BFA, cells were then stained with live/dead and labeled for CD3, CD8, CD1c, CD141, CD123 and HLA-A2, and intracellularly for IFN- $\gamma$, then the percentages of IFN- $\gamma^{+}$cells among $\mathrm{CD}^{+} \mathrm{T}$ cells were analyzed by flow cytometry (38). Wilcoxon test between H9 and H9HIV cells, Mann-Whitney tests (italics) between DC populations.

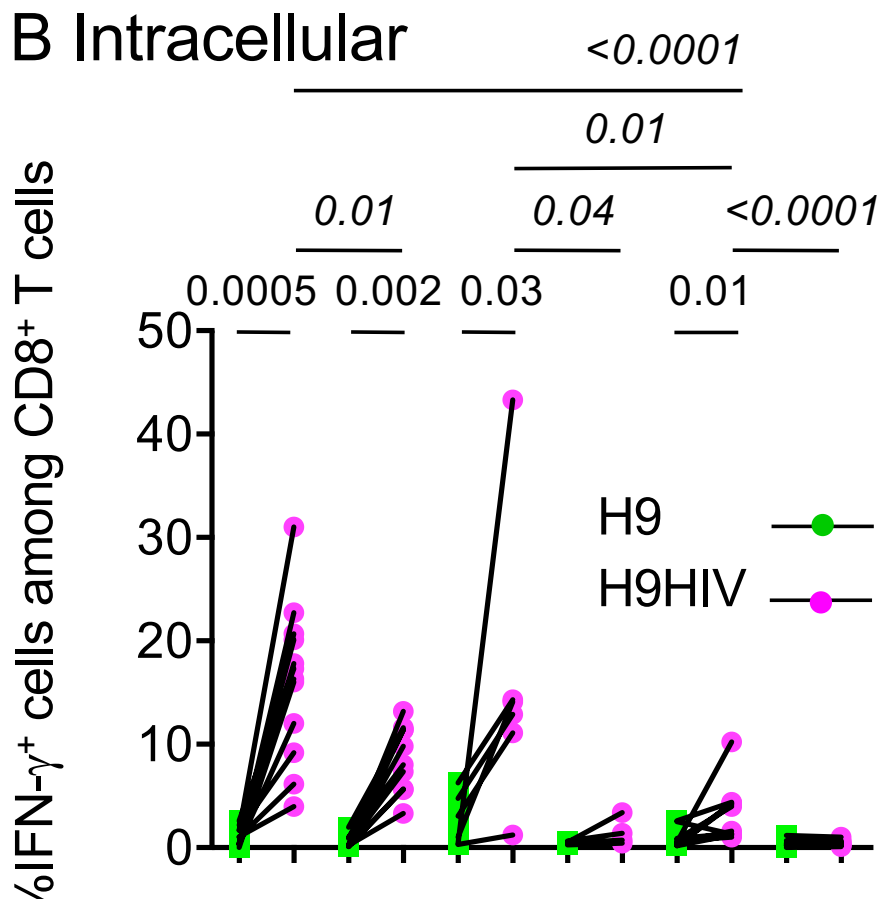

$\mathrm{HLA} \mathrm{A2}{ }^{+} \mathrm{A2}^{-} \mathrm{A2}^{+} \mathrm{A2}^{-} \mathrm{A2}^{+} \mathrm{A} 2^{-}$ $\mathrm{pDC} \quad \mathrm{cDC} 1 \quad \mathrm{cDC} 2$ 
A

DC populations Purified Combined
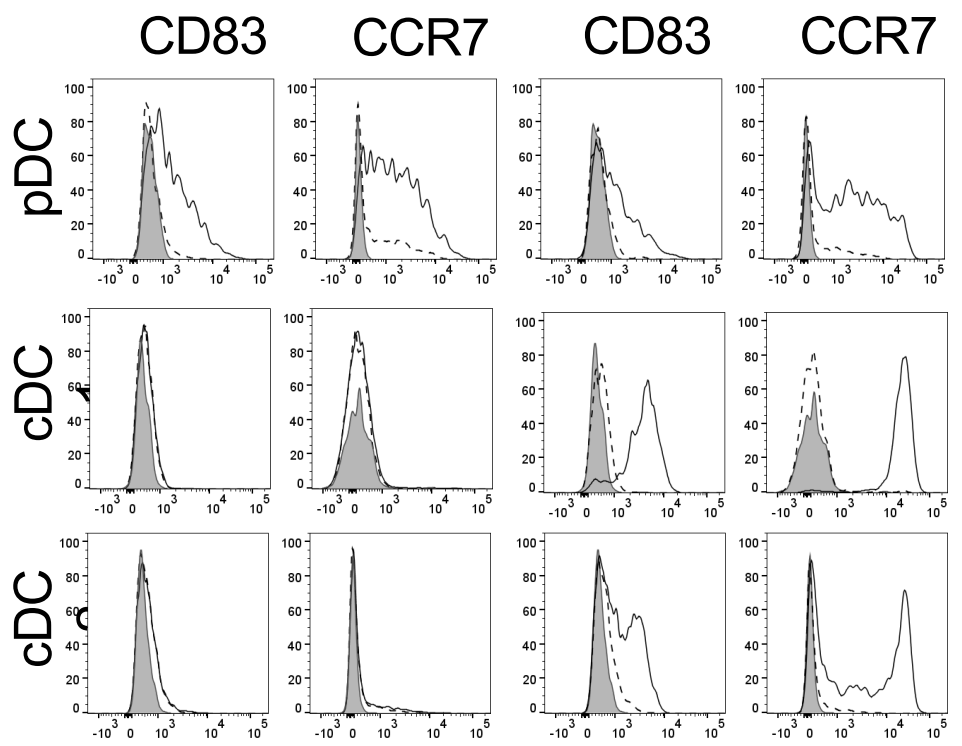

$\square$ Isotype control

$=\mathrm{H}$ H9

H9HIV

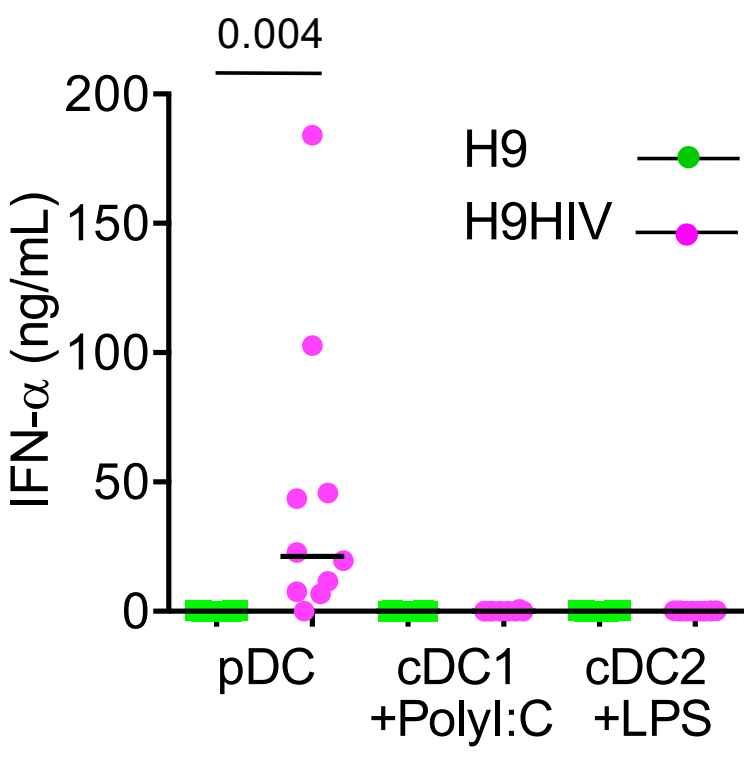

Fig. 2: pDC, not cDC, matured and produced IFN- $\alpha$ in the presence of apoptotic HIVinfected cells

FACS-purified pDC, cDC1 or cDC2 were incubated overnight with apoptotic H9 or H9HIV cells in the presence of survival factors. A. Maturation. Purified DC, either alone (left) or combined (right), were labeled with anti-CCR7 and -CD83 antibodies and analyzed by flow cytometry. One representative experiment out of 3 for $\mathrm{pDC}$ and $\mathrm{cDC} 2$, and of 2 for $\mathrm{cDC} 1$ is shown. $\mathbf{B}$. IFN- $\alpha$ secretion. pDC, $\mathrm{cDC} 1$ stimulated with Poly:IC and $\mathrm{cDC} 2$ stimulated with LPS were incubated for $16 \mathrm{~h}$ in the presence of H9 (green) or H9HIV (magenta) cells. IFN- $\alpha$ secretion was measured in the supernatants by ELISA. $\mathrm{pDC} n=10, \mathrm{cDC} 1 \mathrm{n}=4, \mathrm{cDC} 2 \mathrm{n}=10$. Data are shown with medians. Wilcoxon test for comparison of pDC $+\mathrm{H} 9 \mathrm{HIV}$ and $\mathrm{pDC}+\mathrm{H} 9$ 


\section{Fig. 2}

A
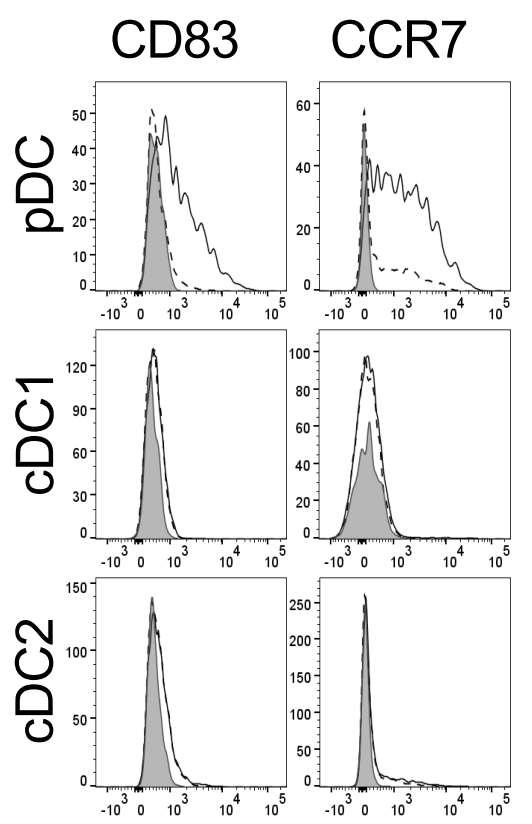

Isotype control

r- H9

$\square \mathrm{H} 9 \mathrm{HIV}$

\section{In the context of the}

other purified DC <avec la

meme présentation qu'à gauche et sans

les H9HIV2>
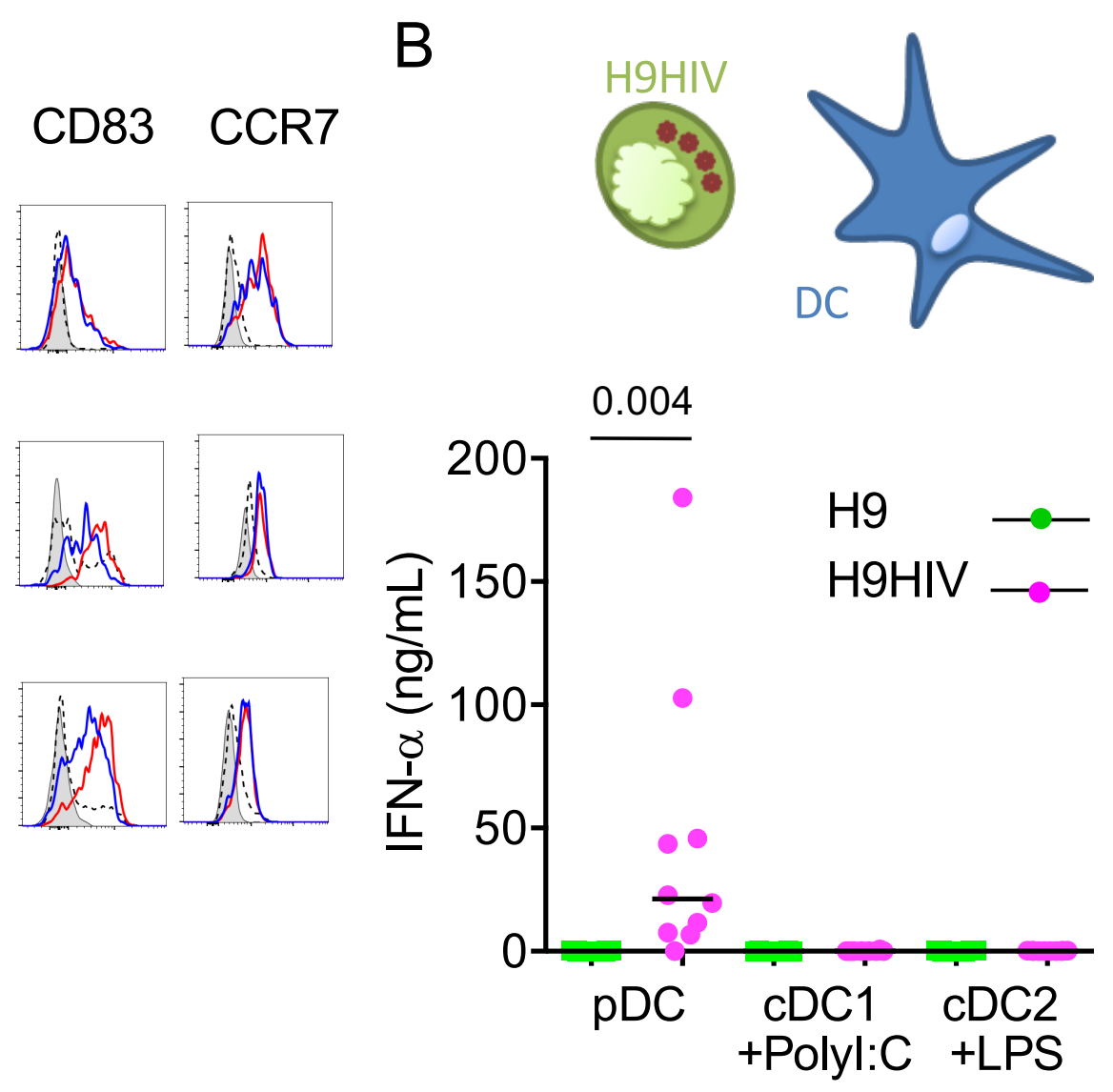

Fig. 2: pDC, not cDC, matured and produced IFN- $\alpha$ in the presence of apoptotic HIVinfected cells

Purified pDC, cDC1 or cDC2 were incubated overnight with apoptotic H9 or H9HIV cells in the presence of survival factors. A. Maturation. Cells were labelled with anti-CCR7 and CD83 antibodies and analyzed by flow cytometry. One representative experiment out of 3 for pDC and $\mathrm{cDC} 2$, and of 2 for $\mathrm{cDC} 1$ is shown. B. IFN- $\alpha$ secretion. $\mathrm{pDC}, \mathrm{cDC} 1$ stimulated with Poly:IC and cDC2 stimulated with LPS were incubated for 16h in the presence of H9 (green) or H9HIV (magenta) cells. IFN- $\alpha$ secretion was measured in the supernatants by ELISA. pDC $\mathrm{n}=10, \mathrm{cDC} 1 \mathrm{n}=4, \mathrm{cDC} 2 \mathrm{n}=10$. Data are shown with medians. Wilcoxon test for comparison of $\mathrm{pDC}+\mathrm{H} 9 \mathrm{HIV}$ and $\mathrm{pDC}+\mathrm{H} 9$ 


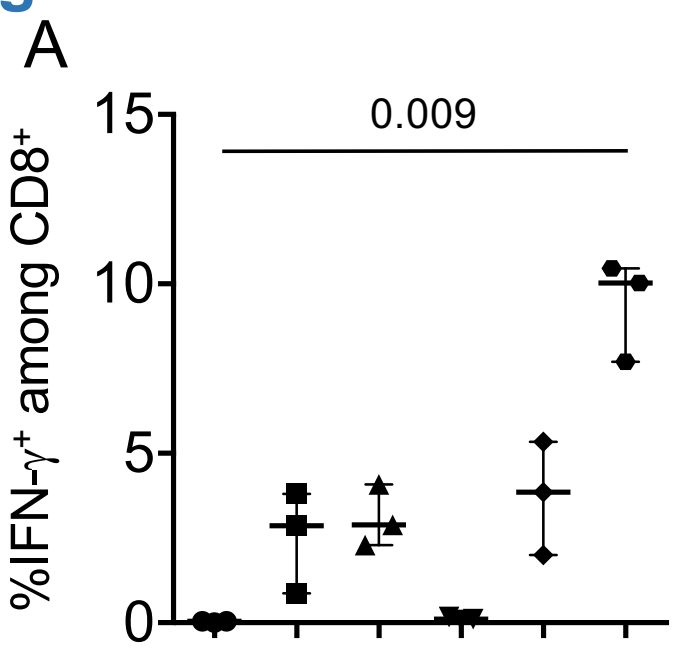

$\begin{array}{lllllll}\text { IFN- } \alpha & - & + & - & - & + & + \\ \text { IFN- } \beta & - & - & + & - & + & + \\ \text { TNF- } \alpha & - & - & - & + & - & +\end{array}$

\section{B IFN-y GzB CD3 merged}

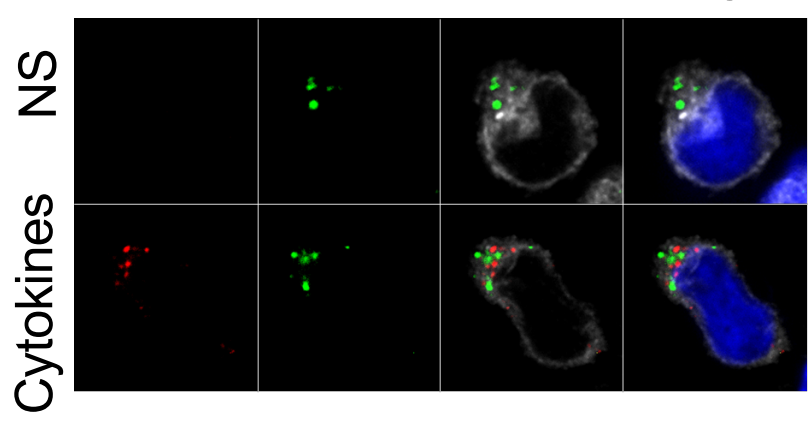

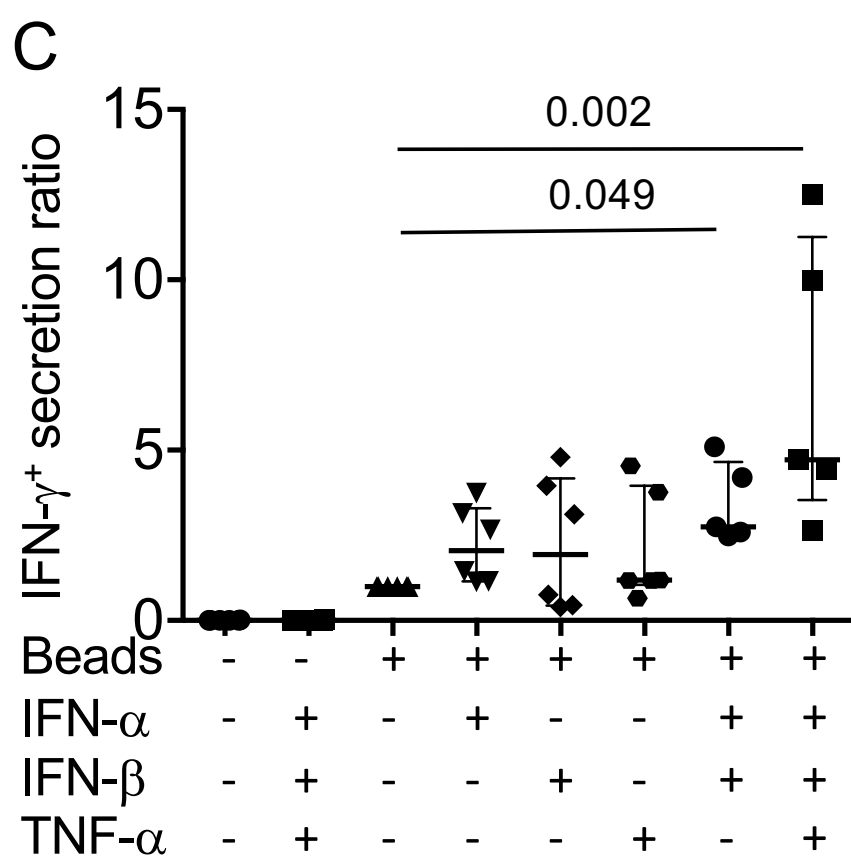

HIV specific CD8 ${ }^{+} \mathrm{T}$ cell

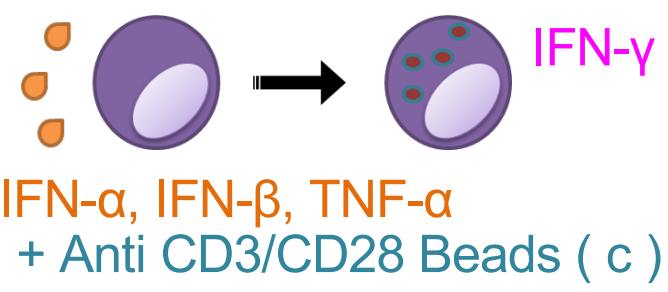

Fig. 3: IFN- $\alpha$ and IFN- $\beta$, potentiated by TNF- $\alpha$, induced by themselves IFN- $\gamma$ intracellular production in $\mathrm{CD8}^{+} \mathrm{T}$ cells and IFN- $\gamma$ secretion upon cognate interaction.

A. Intracellular IFN- $\gamma$ production in response to cytokines alone. Cloned $\mathrm{CD} 8^{+} \mathrm{T}$ cells were stimulated or not for $4 \mathrm{~h}$ with IFN- $\alpha_{2}$, IFN- $\beta$ or TNF- $\alpha$ alone or in combination as indicated. Intracellular IFN- $\gamma$ production was analyzed by flow cytometry $(n=3)$. Data are shown as medians with interquartile ranges. Statistical analysis by Kruskall-Wallis followed by Dunn's multiple comparison post-test. B. Intracellular IFN- $\gamma$ or Granzyme B production. Cloned CD $8^{+}$T cells were stimulated with IFN- $\alpha$, IFN- $\beta$ and TNF- $\alpha$ (Cytokines), or not (NS), for $4 \mathrm{~h}$. The cells were then fixed and permeabilized, then labeled with anti-CD3, anti-Granzyme B and anti-IFN- $\gamma$ antibodies, and with DAPI. They were analyzed by confocal microscopy. IFN- $\gamma$ is shown in red, Granzyme B in green, CD3 in grey and DAPI-stained DNA in blue. NS: image representative of 18/18 cells, Cytokines: image representative of 28/60 cells positive for IFN- $\gamma$. All cells expressed Granzyme B regardless of stimulation. C. IFN- $\gamma$ secretion in response to cognate interaction is potentiated by cytokines. Cloned $\mathrm{CD} 8^{+} \mathrm{T}$ cells were stimulated for $4 \mathrm{~h}$ with IFN- $\alpha_{2}$, IFN- $\beta$ or TNF- $\alpha$, alone or in combination as described in the figure. When indicated, anti-CD3 anti-CD2 8 coated beads were added for $4 \mathrm{~h}$. IFN- $\gamma$ secretion was measured in the supernatant by ELISA. Results were normalized to the beads-only condition, where the median IFN-g concentration was $93 \mathrm{pg} / \mathrm{mL}$ (min 22, maximum 286 $\mathrm{pg} / \mathrm{mL}, \mathrm{n}=6$ ); for other stimulation conditions, $\mathrm{n}=5$ or 6 experiments. Data are shown as medians with interquartile ranges. Medium-only and cytokines-only conditions did not induce IFN- $\gamma$ secretion and were not taken into account for the statistical tests. Statistical analysis by Kruskal-Wallis test followed by Dunn's multiple comparison post-test. 

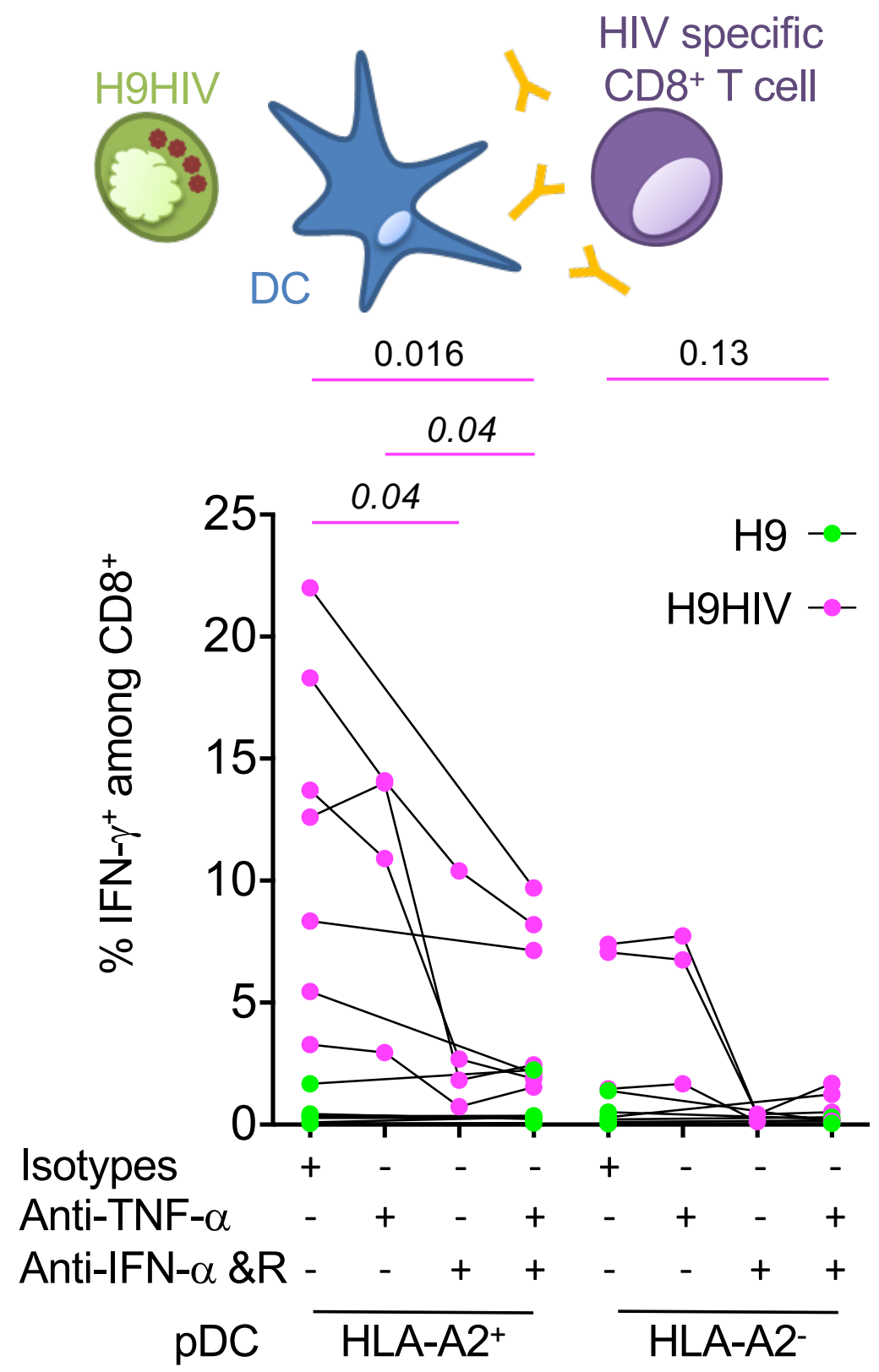

Fig. 4: Antibodies blocking IFN- $\alpha$ and IFNAR abolished IFN- $\gamma$ intracellular production by $C D 8^{+} T$ cells HLA-A2 $^{+}(n=7)$ or HLA-A2 $(n=6)$ purified pDC were cultured overnight with apoptotic H9 (green) or H9HIV (magenta) cells in the presence of IL-3, then incubated with either neutralizing antibodies targeting IFN- $\alpha$ and IFN- $\alpha$ receptor only, TNF- $\alpha$ only or all three $(10 \mu \mathrm{g} / \mathrm{mL}$ each) or isotype controls at the same concentrations (Isotypes), before cloned anti-Gag ${ }_{77-85} \mathrm{CD}^{+} \mathrm{T}$ cells were added. After $4 \mathrm{~h}$ in the presence of BFA, cells were labelled as in Fig. $1 \mathrm{~B}$ and analyzed by flow cytometry. 


\section{Fig. 5}

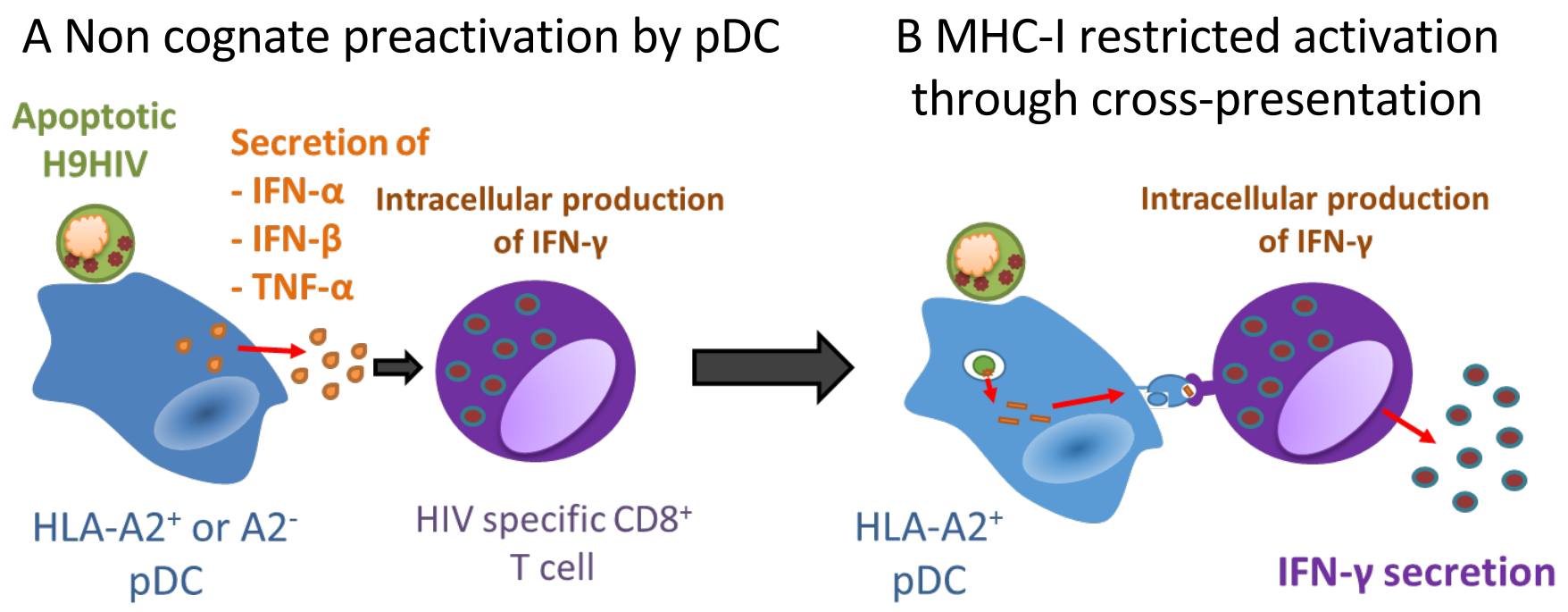

Fig. 5. Model. Cell associated HIV cross-presentation by PDC is potentiated by non-cognate CD8 $\mathrm{T}$ cell preactivation

- HIV-infected H9 cells induce type I IFN production by pDC

- Type I IFN induces IFN- $\gamma$ intracellular production in CD8+ Tcells

- $\mathrm{pDC}$ cross-present MHC-I-restricted HIV-Gag antigen to specific CD8 $8^{+} \mathrm{T}$ cells

- IFN- $\gamma$ secretion by $\mathrm{CD}^{+} \mathrm{T}$ cells is potentiated by former type I IFN stimulation, but occurs only in the case of cognate interaction with pDC 


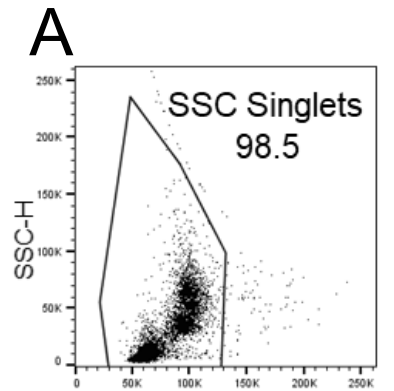

SSC-W
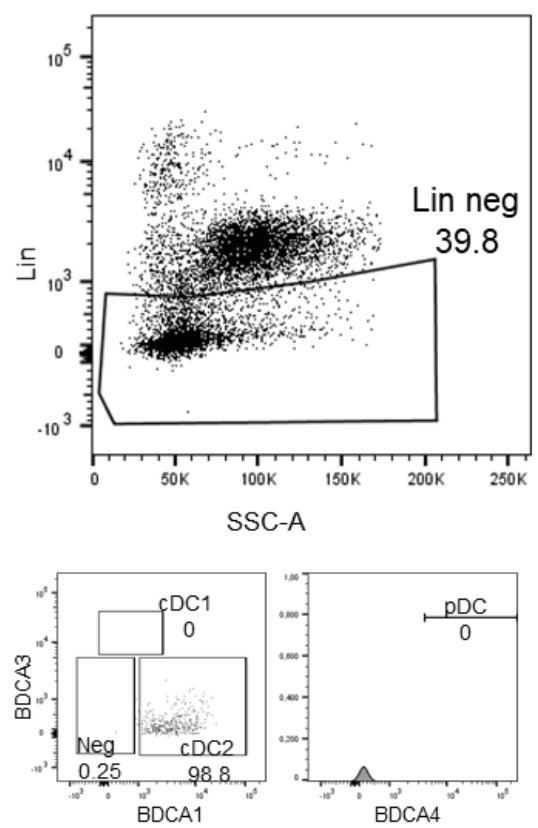
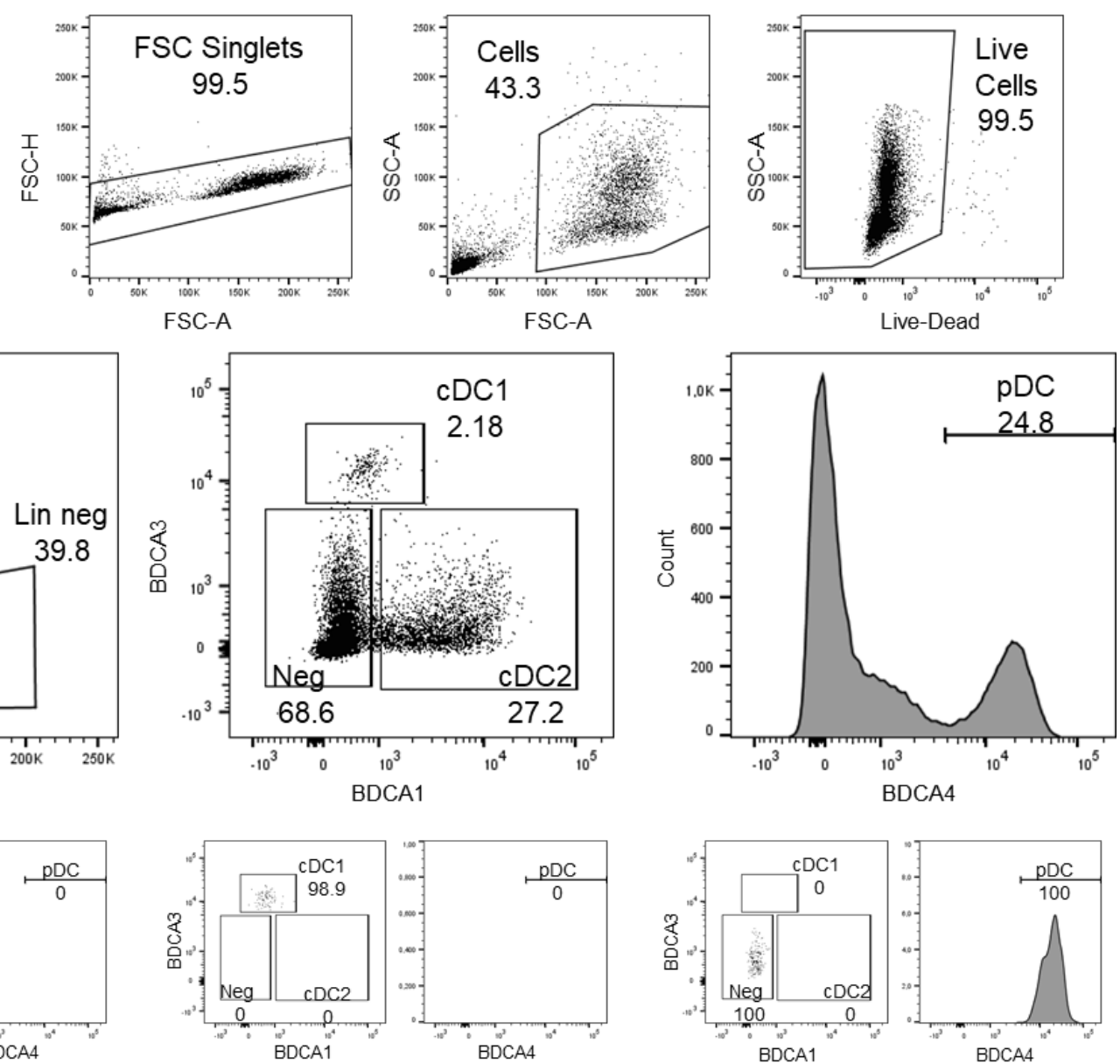

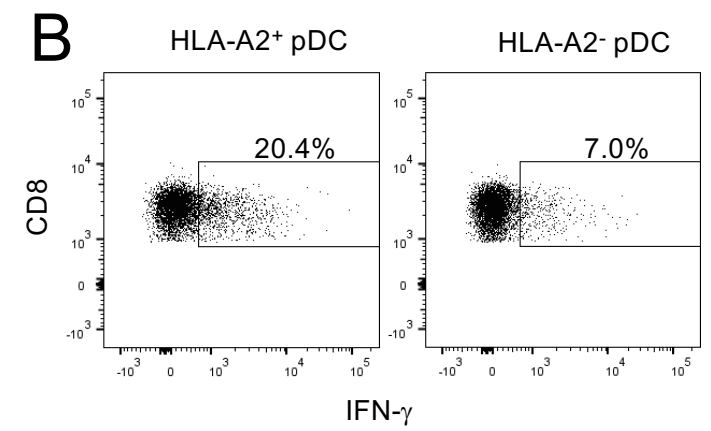

Supplemental Fig. 1: Gating strategies.

A. DC sorting and purity assessment from Pan-DC. SSC then FSC were used to remove doublets. FSC/SSC combination was used to eliminate debris, and dead cells were excluded using Live/Dead dye. Lineage (CD3, CD19, CD20, CD14, CD16 and CD56) negative live cells were then selected and DC were sorted according to CD1c (BDCA1), CD141 (BDCA-3) or CD304 (BDCA-4) expression. Purity of each DC subtype was immediately checked after sorting.

B. IFN- $\gamma$ intracellular production. IFN- $\gamma$ expression was tested by flow cytometry in cloned $\mathrm{CD}^{+} \mathrm{T}$ cells specific for HIV-1 Gag 77-85 after incubation with HLA-A2 ${ }^{+}$(left) DC or HLA-A2- (right) pDC preincubated with H9HIV cells. CD8 ${ }^{+}$cells were gated among $\mathrm{CD}^{+} \mathrm{T}$ cells, which expressed HLA-A2 and not the surface proteins characterizing pDC (CD123) nor other DC (CD141 or CDc1), among live cells not forming doublets. The gating strategy is described in detail in ref (38). 

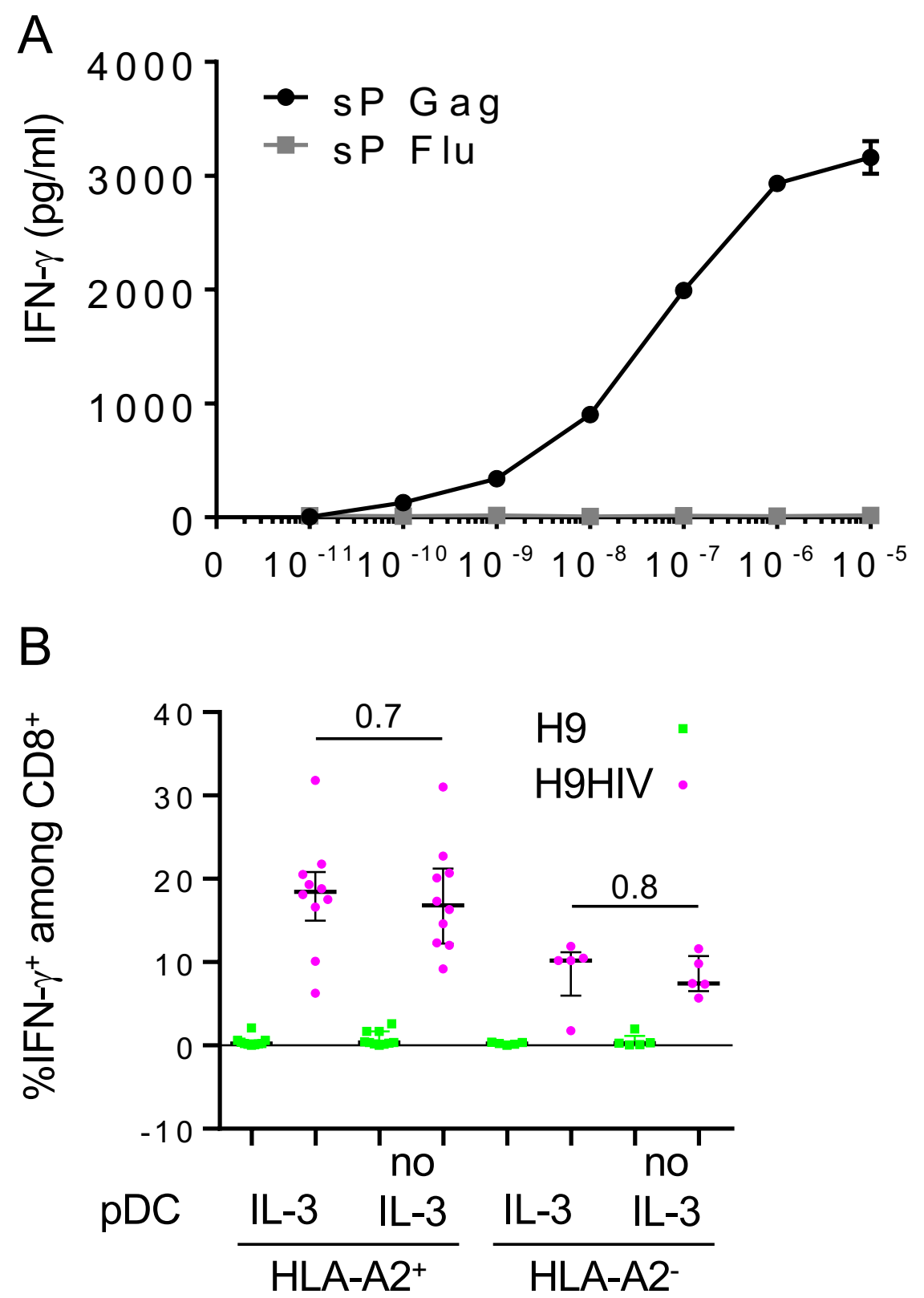

Supplemental Fig. 2: Properties of the anti-HIV CD8 ${ }^{+}$T cell clone. A. Anti HIV-1 $\operatorname{Gag}_{77-85}$-specific $\mathrm{CD}^{+} \mathrm{T}$ cell clone IIB7 specificity test on peptide-pulsed HLA-A2 ${ }^{+}$ EBV-B cell line. sP Gag: HIV-1 $1_{\text {lai }}-\mathrm{Gag}_{77-85}$; sP Flu: IAV (H1N1-A/PR8 ${ }_{58-66}$.

B. IL-3 did not alter IFN- $\gamma$ intracellular production by the $\mathrm{CD}^{+} \mathrm{T}$ cell clone in response to $\mathrm{pDC}$ incubated with apoptotic H9HIV cells. Purified HLA-A2 ${ }^{+}$or HLA-A2- pDC were cultured overnight with apoptotic H9 or H9HIV cells in the presence or absence of IL-3. Cells from the $\mathrm{CD} 8^{+} \mathrm{T}$ cell clone were then added for $4 \mathrm{~h}$ in the presence of BFA. IFN- $\gamma$ intracellular production was assessed by labeling cells as in Fig. 1, and cells were analyzed by flow cytometry. Wilcoxon text between IL-3 and no IL-3 (HLA-A2 ${ }^{+} \mathrm{pDC} n=10$ for both IL-3 and no IL-3, HLA-A2- $\mathrm{pDC} n=5$ for both IL-3 and no IL-3). 